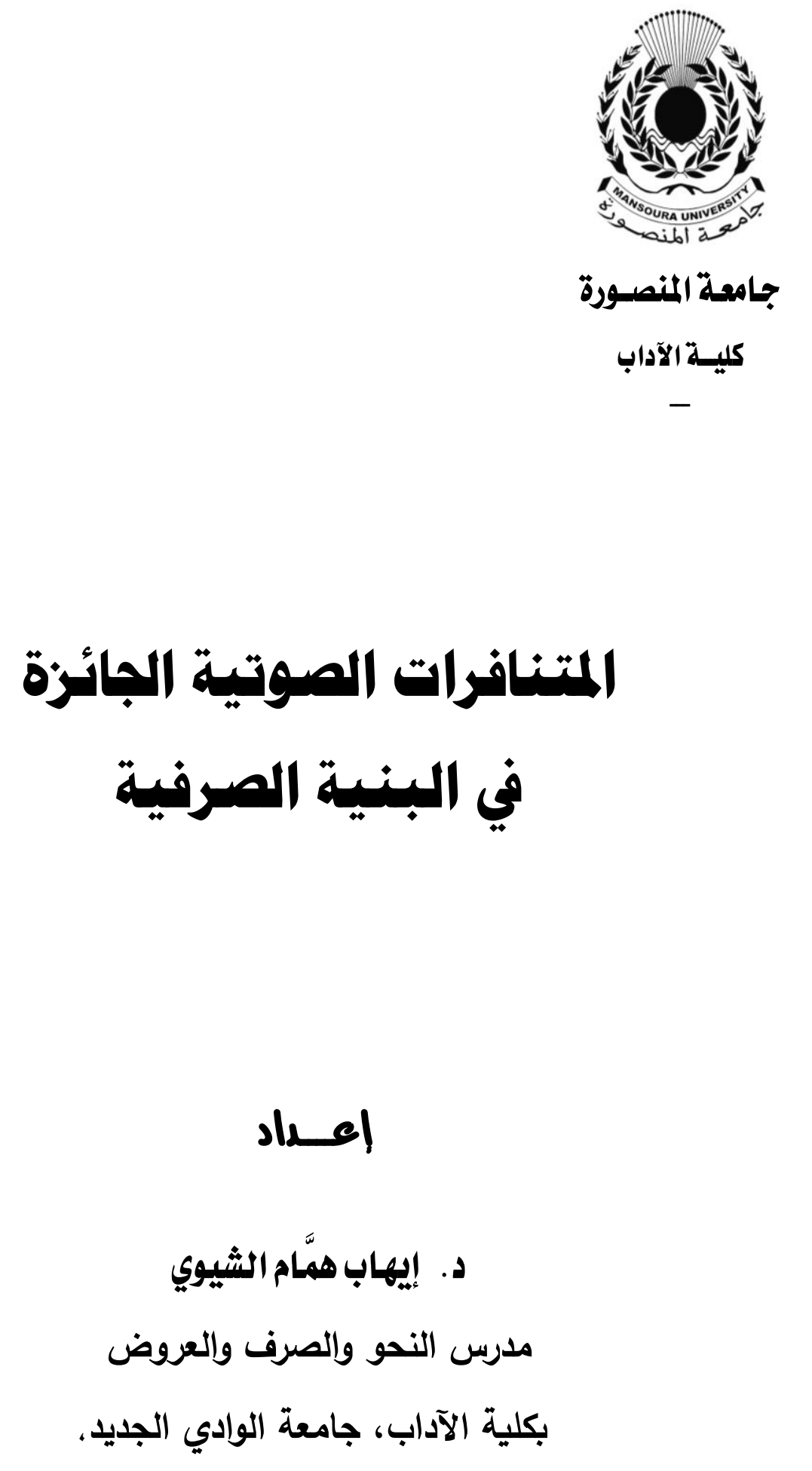




\section{المتنـافرات الصوتية الجائزة في البنية الصرفية}

\section{د. - د. إيهاب همَّام الشيوي}

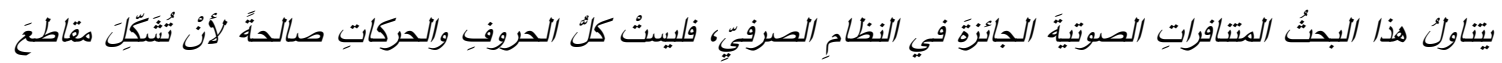

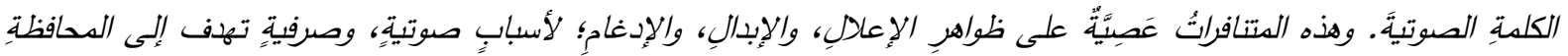

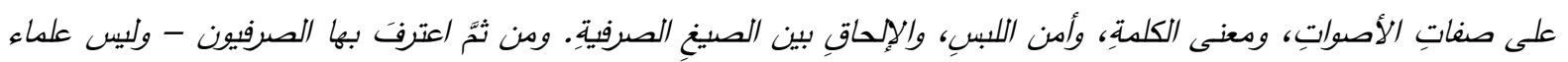

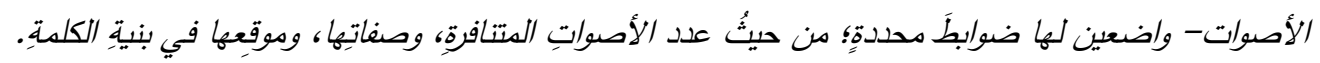

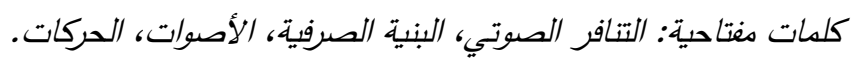

\section{Abstract}

This research paper tackles the permission sound contrasts in the morphological system, not all letters and vawels are valid for formation the sound sections.

These contrasts are disobedient on phenomena of the substitution and the merging, which result from phonetic, and morphological reasons, that aim to preserve the qualities of sounds, the meaning of the word, understanding, and annexation morphological formulas. Hence, The morphologists - not the phonologists - approved it by specific rules of the number of sound contrasts, its qualities, and its location in the word.

Keywords: sound contrast, morphological structure, sounds, vawels.

The study examines the creation and development of fictional characters in the novel entitled

مقدمة

الصرفيةِ، كظواهر الإعـلالِ والإبدالِ بين أصسواتِ

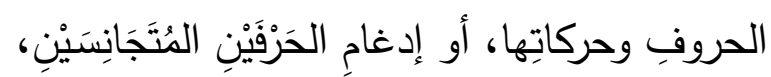

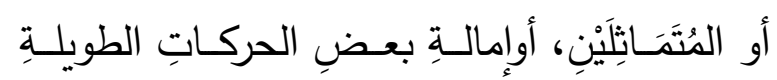
...؛ لكنْ قد تَعْجَزُ هذه الظواهرُ أحيانًا عن حلِّ مشكلةِ التنافرِ الصوتيّ في بعضِ الأبنيةِِ؛ وعِنْدَدٍِ

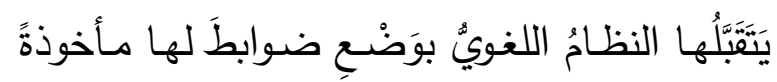

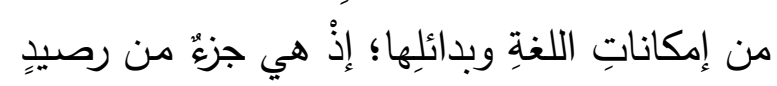
لغويٍّ لله حُجِيَّتُهْ من القراءاتِ القرآنيةِة، ومن أشعارِ العربٍ ومنثوارتِهم.

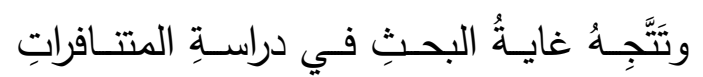
الصـوتيةِ الجائزة في البنية الصـرفية إلى مـا وراءِ ظواهرِ المِّياغةِ الصـرفيةِ التي أَوْجَدَتْ حَلَّل لها؛

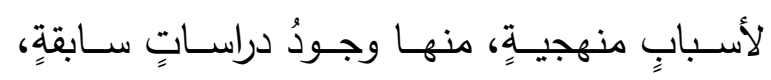
تناولتِ المناسبةَ الصوتيةَ، والقوانينَ الصوتيةَ التي لتِ
الحمـدُ للهِ ربِّ العـالمين، والصـلاةُ والسـلامُ

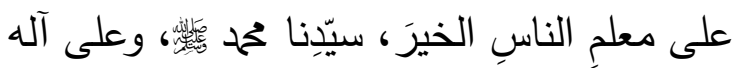

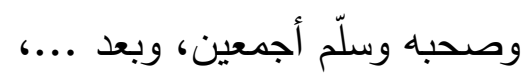

فـإنَّ المناسـبةَ بين أصسواتِ حروفِ الكلمـة

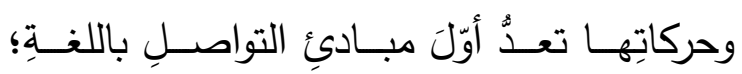
فللصوتِ اللغويّ تأثيرُه على تراكيبِ الكلامِ، وفهِ

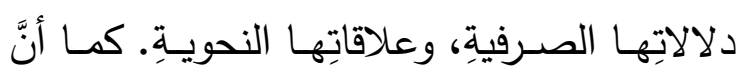

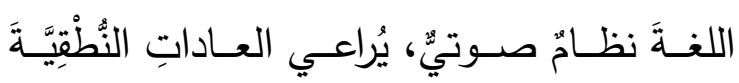
لأصحابِها، وتذوقَهم لأصواتِها وأبنيتِها، تلك التي يُّي

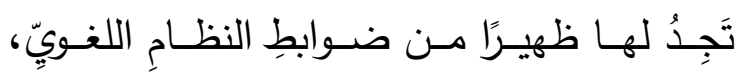
ومقاييسِه المطردةِ.

وفي سـبيلِ هـذه الغايـةِ المنشـودةِِ وَضَـَحَ

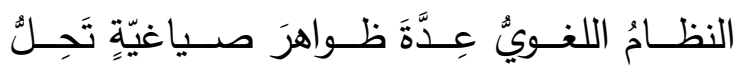

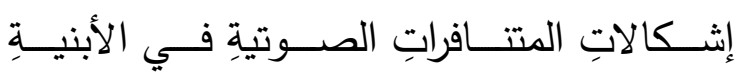


صوتيةٌ فسيولوجيةٌ، قبلَ أنْ تكونَ جزعًا من

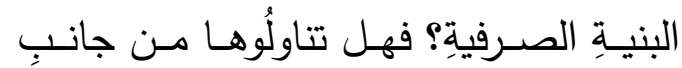

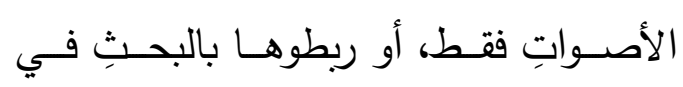

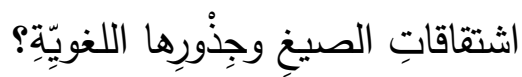

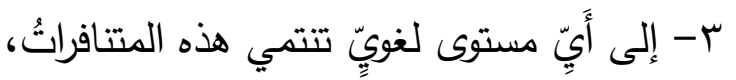

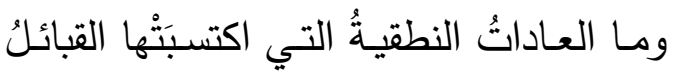
العربيةُ عند تَجَشُّم النطقِ بها، وكيفَ وَجَّهَها الدارسون؟ وما درجةُ اطرادِها في الاستعمالِ بهاِ

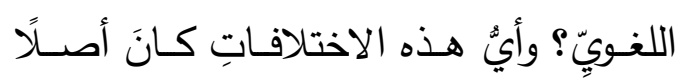
لـآخرِ

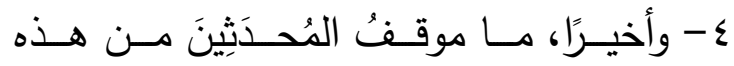

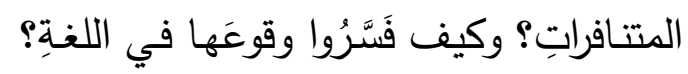

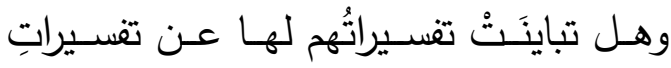
علمائنا القدامى؟ تئي

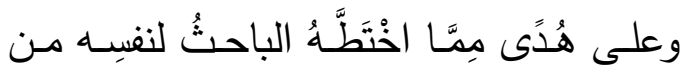
أهدافٍ في دراسةِ أبرزِ المتنافراتِ الصوتيةِ الجائزةِ،

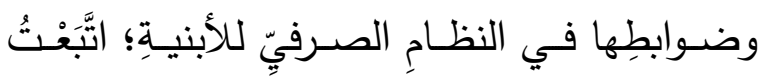

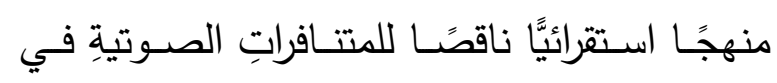

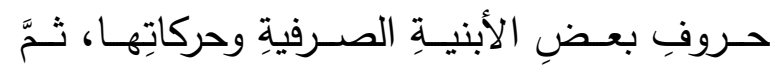

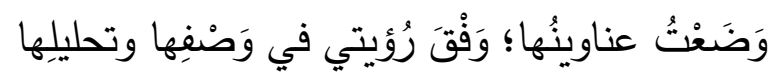

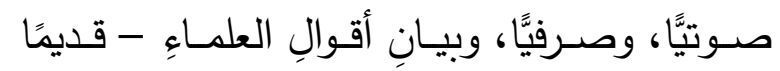

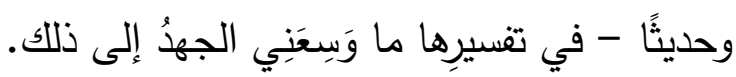

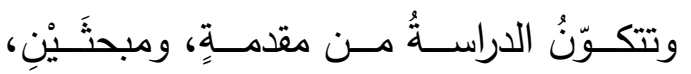
وخاتمةِ، وفهرسٍ، وقد عَنْوَنْتُ المبحشين بالآتي: ا - المبحـث الأول: المتـــافراتُ الصــوتيةُ فــي حروفِ الكلمةِ. r - المبحث الثـاني: المتــافراتُ الصـوتيةُ فـي توالِي الحركاتِ.

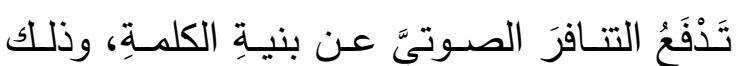

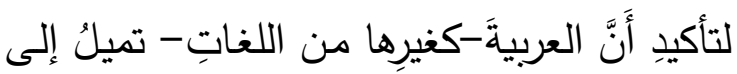

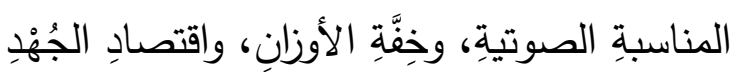

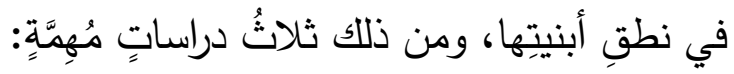

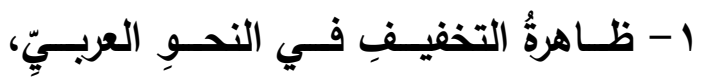

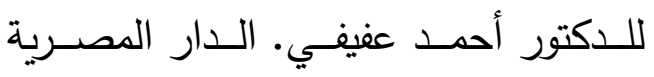

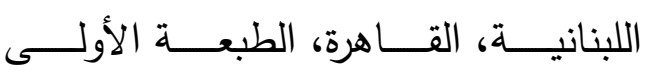
. $997 / 81$ / 99 r - التـــافرُ الصــوتيُّ والظـــاهرُ الســياقيةُ، للدكتور عبد الواحد حسن الثيخ. مكتبـة

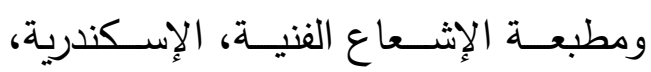

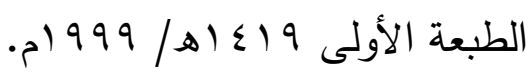
r- أثرُ القوانين الصسوتيةِ في بنـاءِ الكلمـةِة

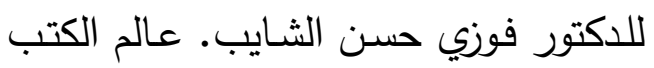

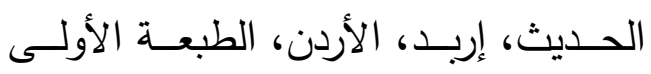

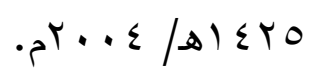

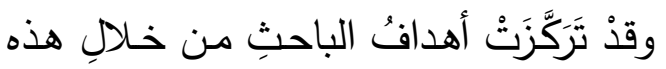

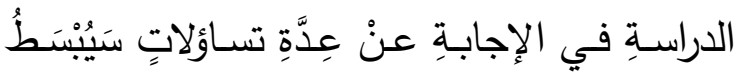
النِقَّاشُ حولَها، وهي كالآتي: 1 - ما موقفُ الدرسِ الصوتيّي - قديمًا وحديثًا-

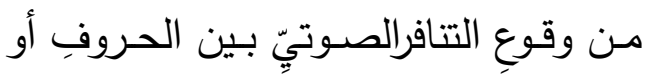

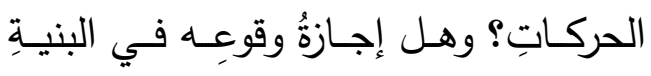

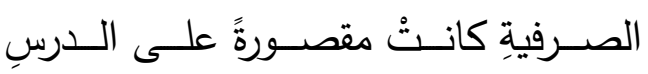

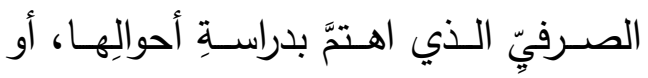

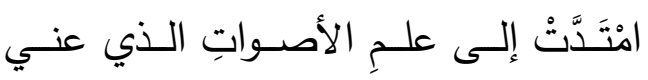

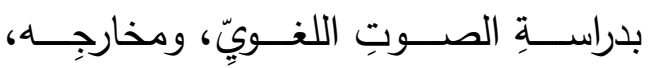

وصفاتِه، ومقاطعِه في بنيةِ الكلمةِ؟

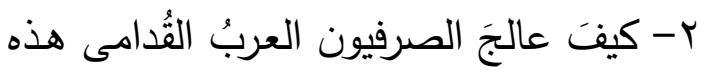

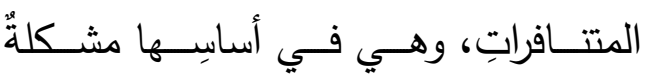




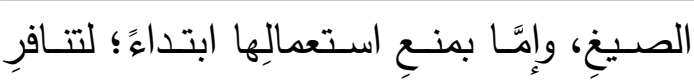

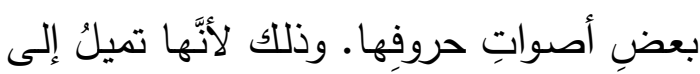

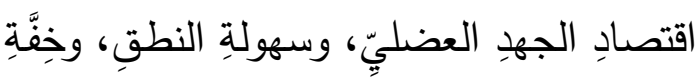

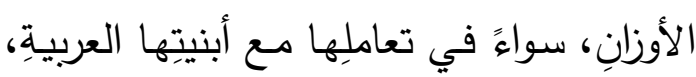
أو في تعريبِ الألفاظِ الأعجميةِ الوافدةٍ إليها.

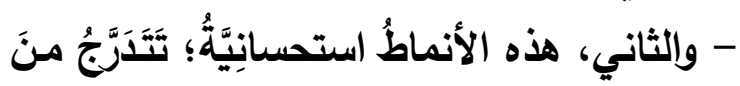

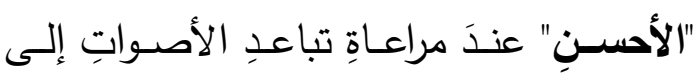

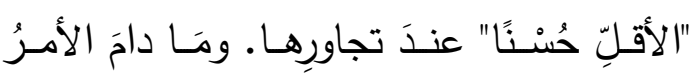

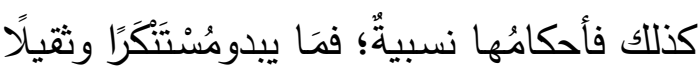

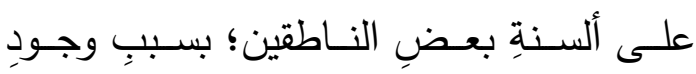
بعضِ المتنافراتِ الصوتيةِ قد يكونُ مستساغًا

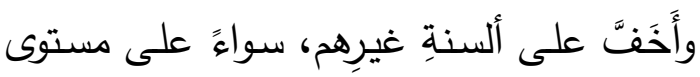
لهجاتِ اللغةِ الواحدةِ، أو على مستوى اللغاتِ

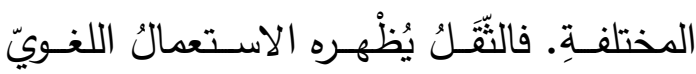
بطريقة عملية تعكس عَاداتِ أهل اللغة أنفسهر

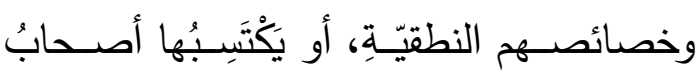

$$
\text { اللغاتِ الأخرى بالتعلُّم (؟). }
$$

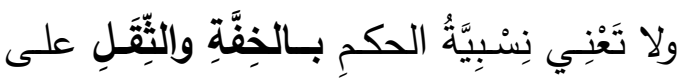

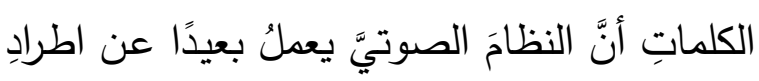

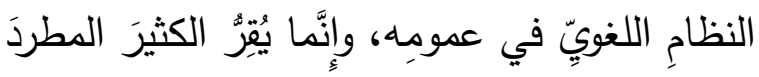

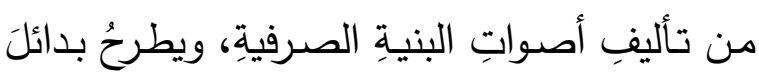

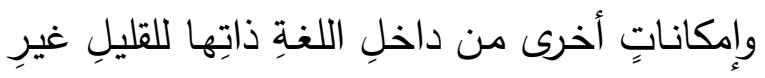

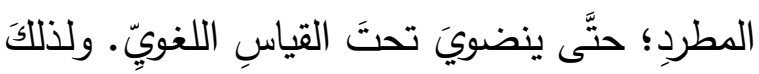

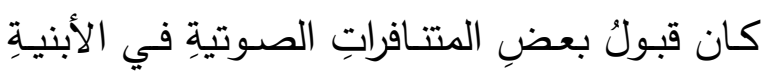

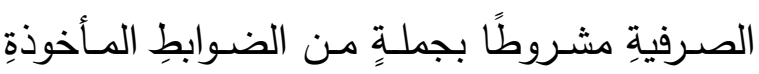

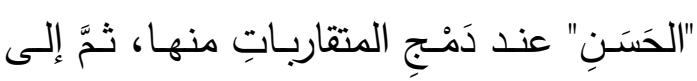

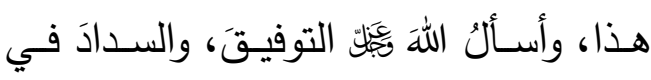

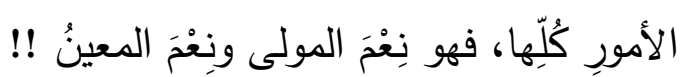

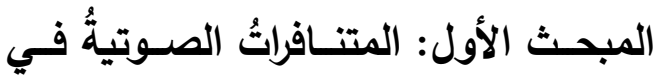
حروفِ الكلمة لا يمكنُ إغفالُ تأثيرِ الصوتِ اللغويّ على

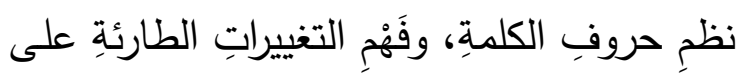

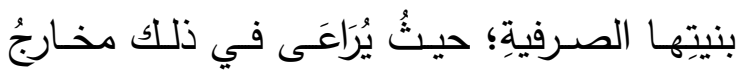
الحروفِ وصفاتُها، والتتاسبُ بين أصواتِها. ولعل فئل

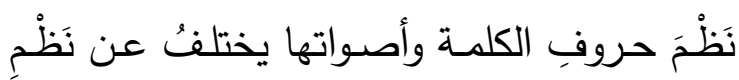

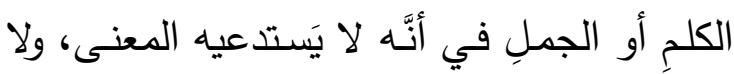

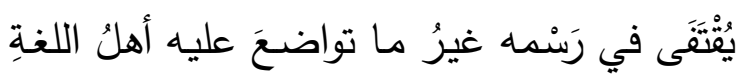

أنفسُهم (1)

وقد استقرأ علماء العربية من النظام اللغوي ثلاثة أنماط في تأليف حروف الكلمة وأصواتها: أوَّلها، نظم الكلمة من حروف متباعدة أصسواتها في المخـرج والصـفات، وهوالأحسـن و وثانيهـا،

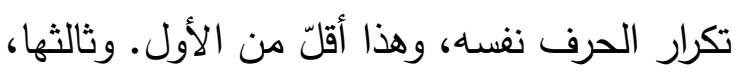

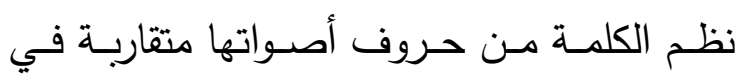
الصفات، ومتجاورة في المخارج، وهذا النمط أقل فئل

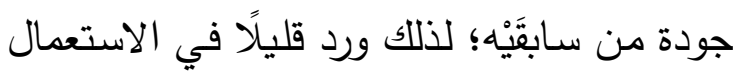

\section{ويُئَْذَُّ مِنْ هذه الأنماطِ نتيجتان:}

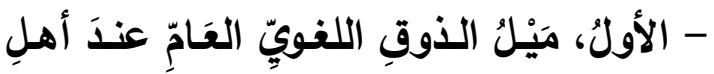

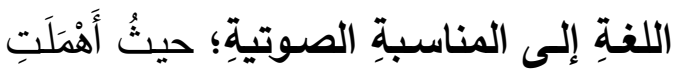

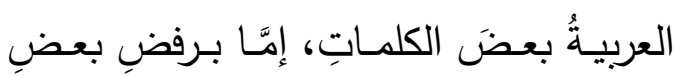

(') انظر نظم الحروف، ونظم الكلم في: دلائل الإعجـاز ، لعبد

القاهر الجرجاني (9 § ؟).

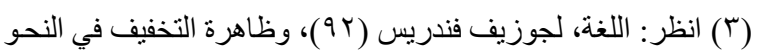

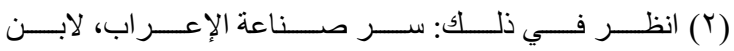
العربي، للاكتور أحمد عفيفي (•r). 
ومخرجُها من أقصى الحَلْقِ، فـ "العينُ، والحـاءُ"،

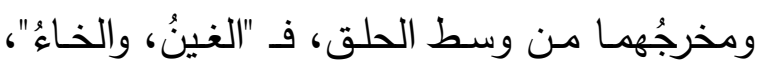
ومخرجُها من أدنى الحلقي.

وتَنْحِِرُ صفاتُ حروفِ الحلقِ في جَرْسَيْنِ

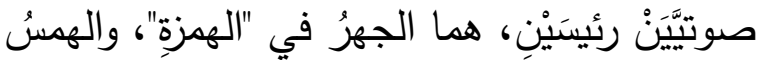

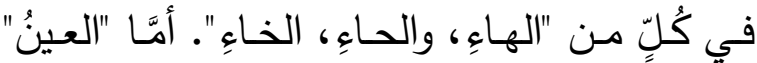

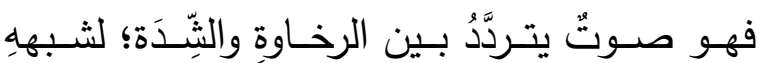
بصوتِ "الحاء"(0). أما "الغين" فصوتُ مُسَتَعْلِ.

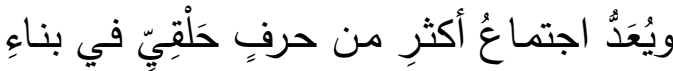

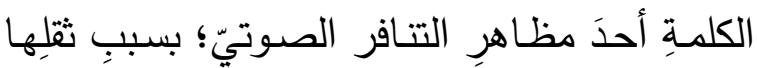

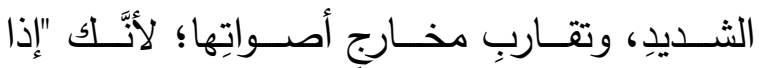
استعملََ اللسانَ في حروفِ الحلقِ، دونَ حروفِ

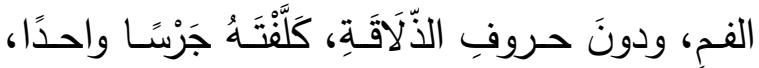
وحركاتٍ مختلفةً ..."( ). (7). ولا يقتصرُ ثُقلُ هذه الحروفِ عندَ الصرفيين العـرب على اجتمـاع بعضِ أصـواتِها في كلمـةٍ واحدةٍ، بلْ يعودُ أيضًا إلى طبيعةِِ مخرجها البعيدِ من جهاز النطق، فقدْ تشتملُ الكلمةُ على حرفٍ

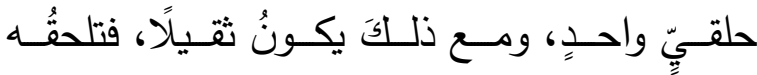

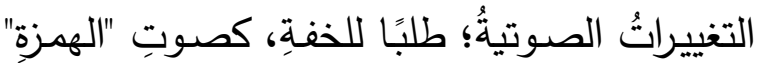
الحلقي، وصفته الجهر والثدة، وإخراجه كالتَّهَوُُع

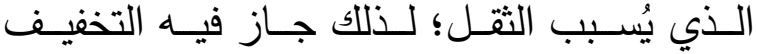

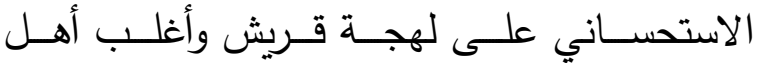
الحجاز • ورغم ذللك فإن أهل تميم وقيس يُحمِّقانه، كغيره من حروف العربية (v).

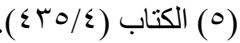

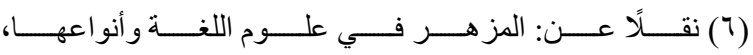
للسيوطي (19)/ (19).

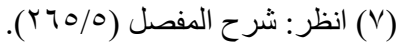

من استقراءِ كلام العرب؛، نستعرضُهـا في النقاطِ

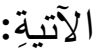

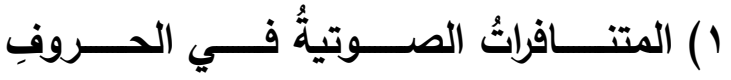

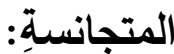
يَتَحَانَّى الاستعمالُ اللغويُّ اجتماعَ الأمثالِ،

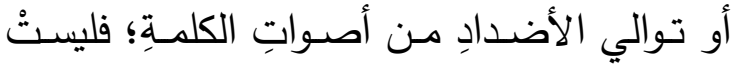

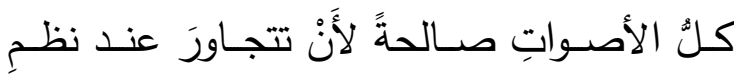

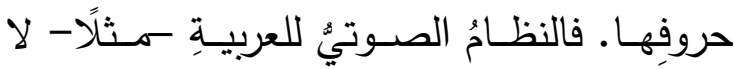

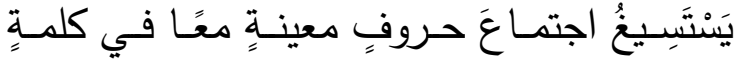

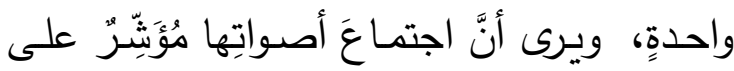
عُجْمَة ألفاظها؛ لـخالفِتِها نظامَ الأصواتِ العربيةِ

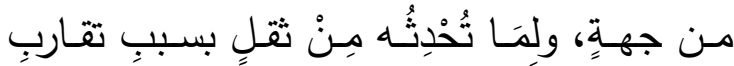

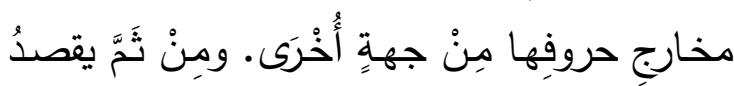

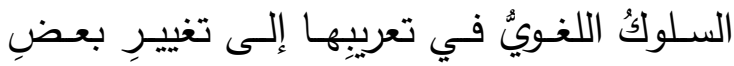

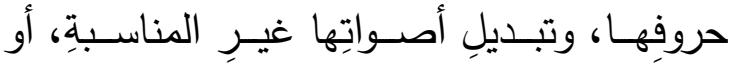

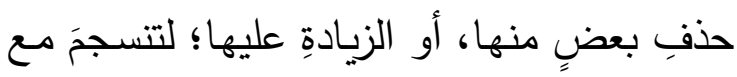
النظامِ الاشتقاقيّ للعربيةِة، وتوافقَ عاداتِ العربِ النطقيَّة عندَ الممارسِة اللغويةِ (ع). وسيقفُ البحثُ أمام طائفتين من المتتافراتِ

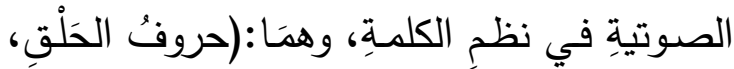

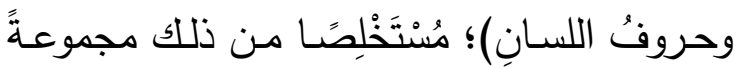
من الضوابطِ التي وضعَها النظامُ اللغويّ لقبولِ التنافرِ الصوتيّ في البنيةِ الصرفيةِ: المتنافراتُ الصوتيةُُ من الحروفِ الحَلْقِيَّةِ:

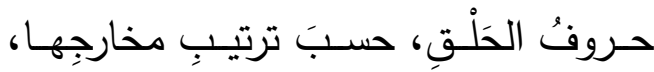

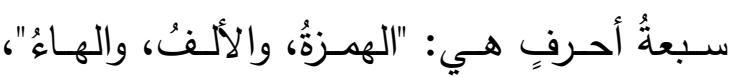

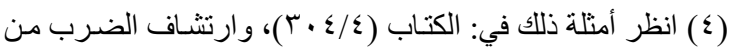

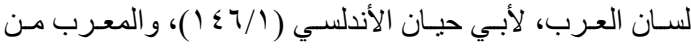
الكلام الأعجمي، لأبي منصور الجواليقي (19 09، 7). 


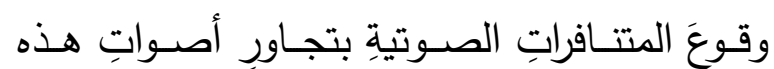

الحروفِ بِعِدَّة ضوابطَ هي كالَاتي (1) أولًَا - الضَّابطُ الكَمِيَيُّ:

اشترط الصرفيون ألَّل يتجاوزَ عددُ المتنافراتِ في بنيـةِ الكلمـةِ صـوتَيَنِ لحـرفَيْنِ مُتجانسَـيْنِ في

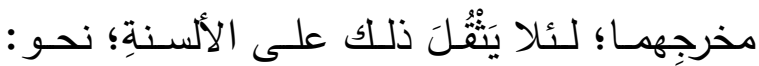

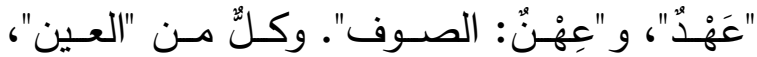

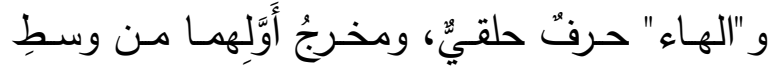
الحلــقي، ويتـردَّد جرسُــهـ الصـــوتيُّ بــين الجهـرِ

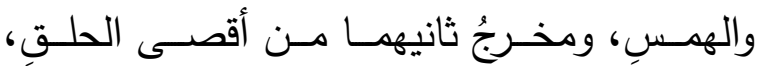
ويتَّصـفُ بـالهمسِ والرخـاوةِ. وليس التقـاربُ بـينَ

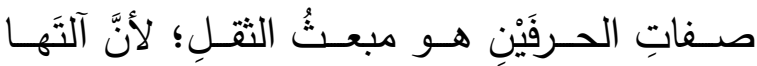

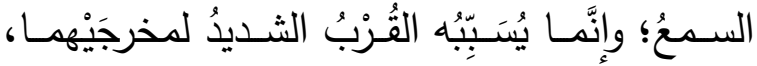

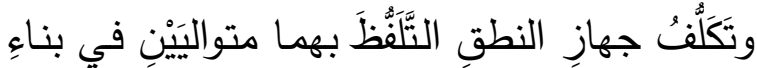

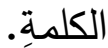

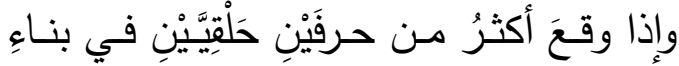

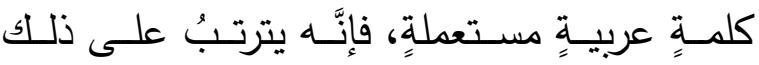

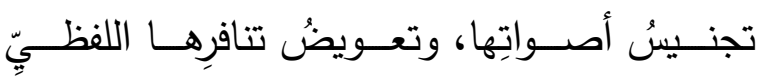
بالانسـام الصـوتيّ، أو بالإدغام، كمـا في كلمـة:

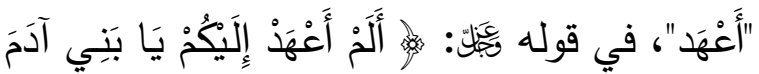

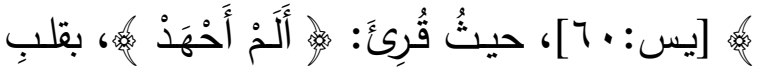
"العين" "حـاءً"؛ بتأثيرِ من "الههاء" المهموسـةِ، وقد

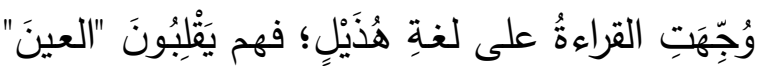

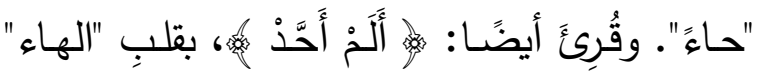

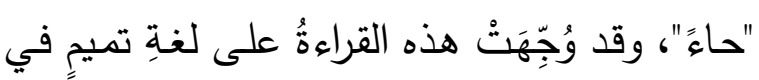

(1) انظـر هـذه الضـوابط في: الخصـائص (1/ 00، 07)، وسـر

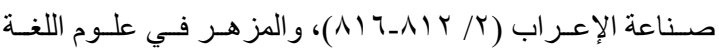

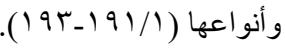

كمَا أنَّ الحرفَ الحلقيَّ يزداد ثقلًا في حالِ

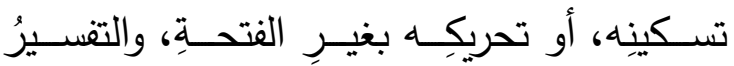
العلمسيُّ لـذللك -على حـدّ قـول الـدكتور عبـده الراجحيّ - أنَّ نطق أصوات الحلق يتطلبُ اتَّـاعَ مجراها الحلقيّ في الفم؛ لذلك كانت حركة الفتحة أكثر أصــوات اللـين مناسـبة مـن غيرهـا لـذلك

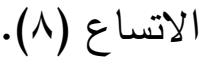
وعلى هُدَى من هذا التفسيرِ يمكنُ أنْ نفهَ لمـاذا جعلَ الصرفيون العربُ بنـاءَ "فَعَل، يَفْعَل"، مفتوحَ العين في المضارع خَاصَّا بِكُلِّ فعلٍ حلقيّ

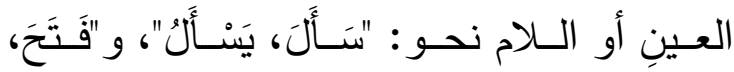
يَفْتَحُ"، وفِي غيـرِ هـا البنـاءِ يجـوزُ الكسـرُ ، أو

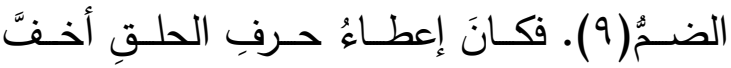
الحركاتِ، وهي الفتحهُ، مناسبًا لطبيعتِه الثقيلةِة، وتحاميًا لمضـاعفةِ الثقـلِ؛ إذا حُرِّكَ بالكسـرة أو الضمةِ الثتيلتَيْنِ. وهذه الظاهرةٌ شائعةٌّ في اللغاتِ الساميةِ، يقولِ بروكلمان: "الفعل "فَتَحَ" مضـارعُه في العربيةِ "يَفْتَحُ، وفي الحبشيةِ yefta-h، وفي

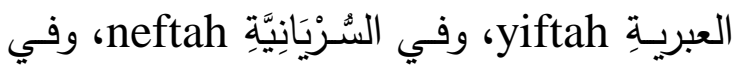

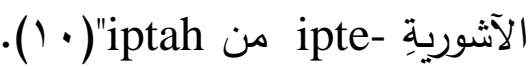
وإذا كانَ حرفُ الحلقِ ثقيلًا في نفِسه، فمِنْ بابِ أولى أنْ يكونَ تجاورُ أكثرِ من حرفٍ حلقيّ أشََّّ ثقلًَا، ومع ذلك سوَّغَ النظامُ الصرفيُّ للعربيةِ

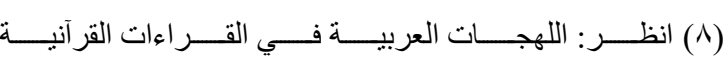

(1) (1) $111 \%)$

(9) انظر : شـرح شـافية ابن الحاجب، لرضـي الدين الأستر اباذي (1)

( (IrN/I)

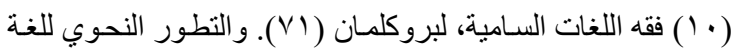
العربية، لبرجشتر اسر (Tآ). 


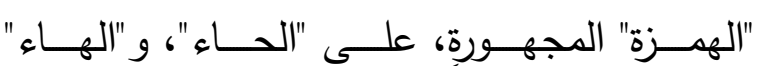

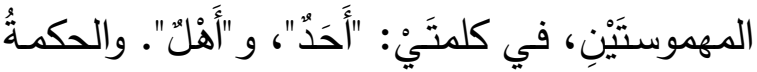
من تقديم الأقوى جَرْسَا أنَّهَ سابقُ على الأضـعفِ

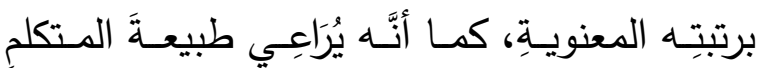
الفسيولوجيةَ، إذْ يكونُ في بداية نطقِهَ أقوى نَفَسًا، وأكثر نشاطًا (ع () ). ثالثًا - الضَّابطُ النّوعِيُّ:

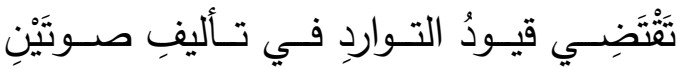

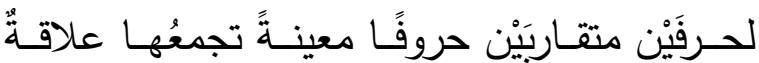

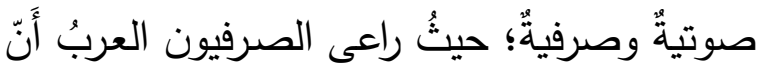

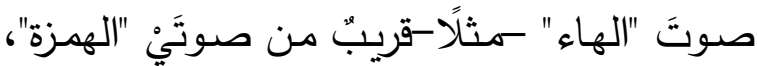

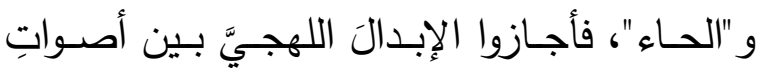

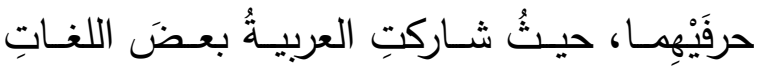

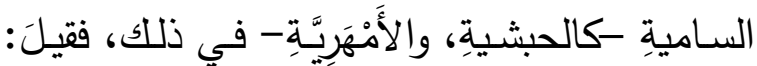
"أَرَاقَ، وهَرَاقَ"، و "مَدَحَ، ومَدَه"(10 (1) .

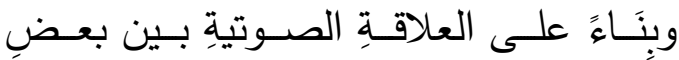
حروفِ الحلقِ؛ سَوَّغَ النظامُ الصرفيُّ توالي "الهمزة،

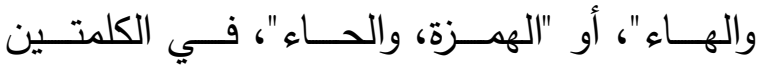

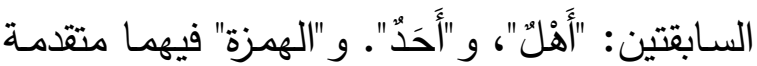
غالبَا؛ لقوة جربـها، ولا تتأخرُ إلا لعلةٍِ صـرفيةٍة

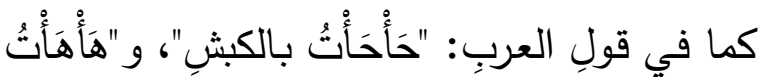

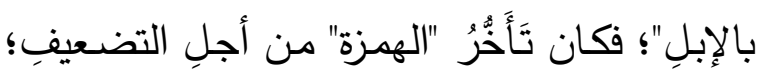

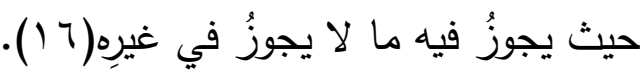
والملاحظُ على هذه الضوابطِ في مُجملِهِا أنَّها

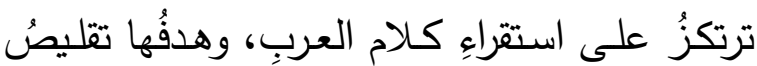

$$
\text { ( (1 ) انظر: الخصائص (1/ 00، 07). }
$$

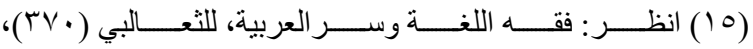

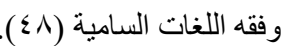

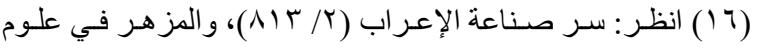

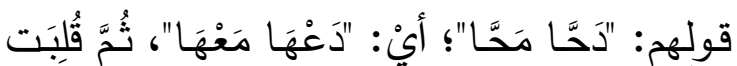
"العينُ" "حاءً"؛ إيذانًا بإدغام المِتْلَيْنِ ( ا (). فالتجنيسُ الصسوتئي في القراءتَنِْن السـابقتَيْنِ

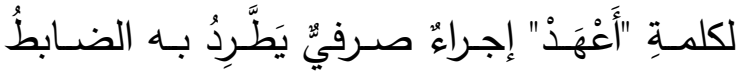

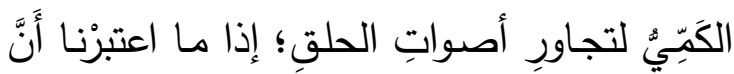
"الهمزة" ليستْ من بناءِ الفعل المُجَرَّدِ "عَهِدَ"؛ أبيْ

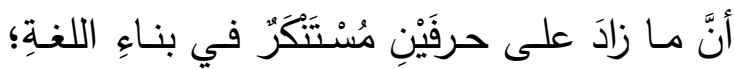
لتتافره وثقِله، وبُعْدِه عن نظامِ تأليفِ الأصواتِ

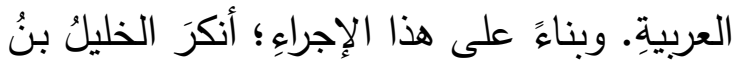

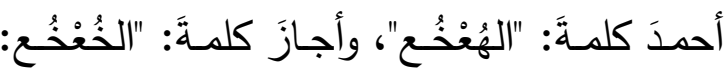

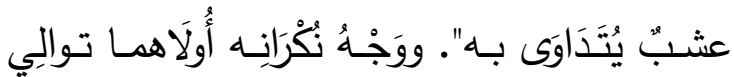

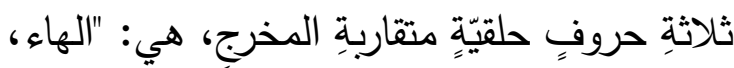
والعين، والخاء"، وهذا غيرُ جائزٍ في تأليفِ كلامِ

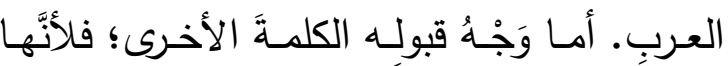

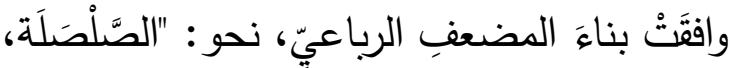

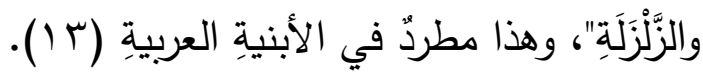

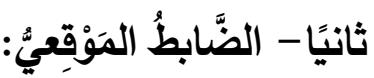

يَتَوَقَّفُ قبولُ المتنافراتِ الصـوتيةِ في بنيـةِ

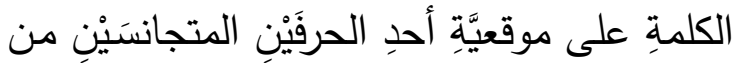

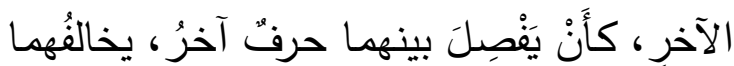

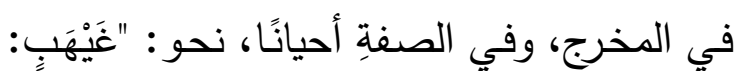

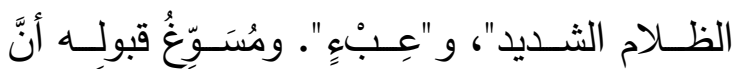
صـوتَ الحرفِ الفاصـلِ باعَدَ بـين مخرجَيْهِهـا؛

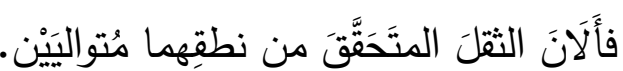

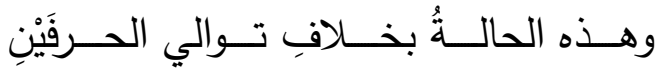

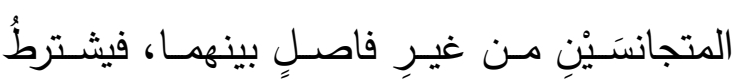

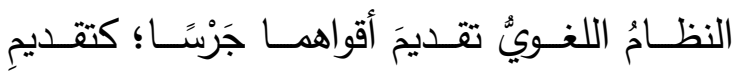


صَوْتَيْ الحرفَيْنِ المتنافرَيْنِ، من غيرِ فصلٍ بينهما في بنيةِ الكلمةِ؛ فكانَ ذلكَّ أسهلَ عليهم من النطقِ بالحرفَيْنِ المتقاربَيَنِ.

وينســـبُ ذلــك الســلوكُ علــى العاميَّـاتِ

المعاصرة، ففي العاميَّةِة المصريـِ-مثثلًا يقولون

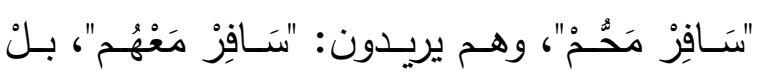

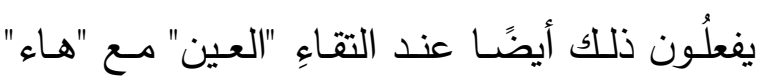

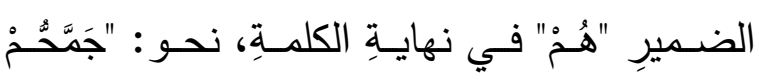
عندي"، وهم يريدون: "جَمَّعُهُمِ عندي". ولعلَّ هذا يـدعونا إلى ضــرورِ التوفيتِ بـين العُرْفِ اللغـويّ الخـاصِّ بــالمتكلمِ فـي تـأليفِ أصــواتِ الكلمـــِ

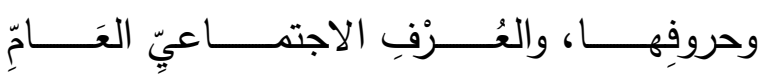
(النظامِ اللغويّ)؛؛ فالمستوى الصـوابيٌّ لمتكلمِ اللغـةِ

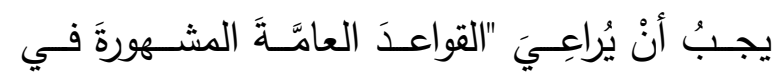
صياغةِِ الكلامِ والعباراتِ، على حسبِ نظامِ اللغـةِ المسـتعملةِ في الأصــواتِ، والصـيخِ، والمفـرداتِ، وتأليفِ الكلامِ"(1) (1). المتنافراتُ الصوتيةُ من الحروفِ اللسانيةِة

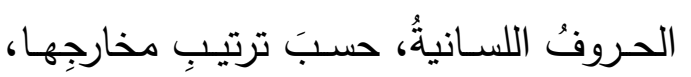

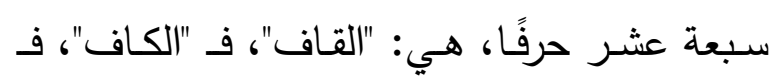

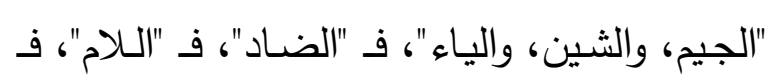

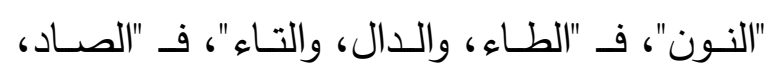
والزاي، والسين"، فـ "الظاء، والثاء، والذال".

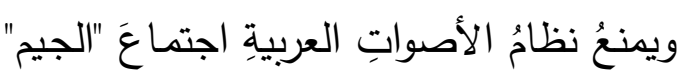
مع "القاف" في كلمةٍ واحدةٍ، أو توالي "الصساد" مـع الصع

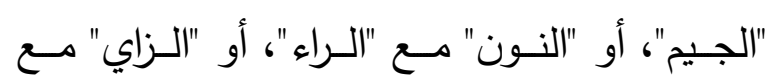

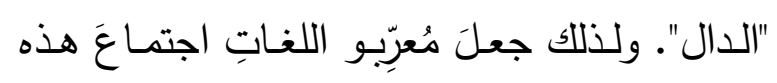

(1) (1) المستوى اللغوي للفصحى و اللهجـات وللنتثر و الثـعر ، للدكتور محمد عيد (T). (T).
دائرةِ المتــافراتِ الصـوتيةِ في حـروفِ الكلمـةِ؛ بوضحِ شروطِ محددةٍ لها، تتعلقُ بعددِ الأصسواتِ

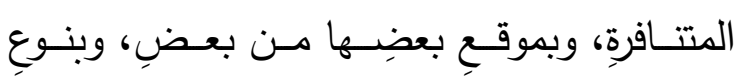
الحروفِ فيها، وبأحكامِها في ظواهرِ الصياغةِ

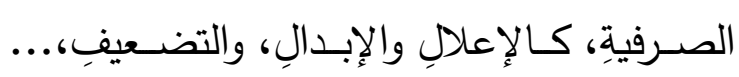
وغيرها. ويمكن القولُ بأنَّ هذه الضوابطَ -بمفهوم

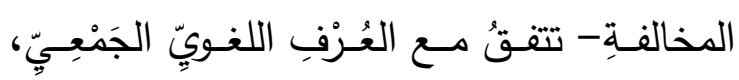
والـوقِ العـامّ في تـأليفِ الأصــاتِ اللغويـةِ في الميلِ إلى الاقتصـادِ في الجهدِ، والسـهولِّفِ في النطقيِ. ورغم أنَّ النظـامَ اللغـويَّ يُبِيحُ للمـتكلم في

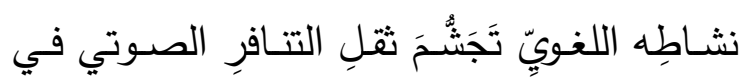
بنـاء الكلمـة؛ فإنَّهَه قد يستعينُ بظـواهرِ الإعـلالِ

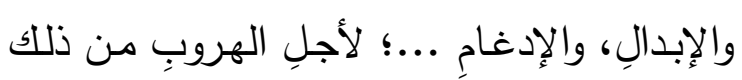
الثقل، وهذا هو الشـائعُ في الاستعمال اللغوي.

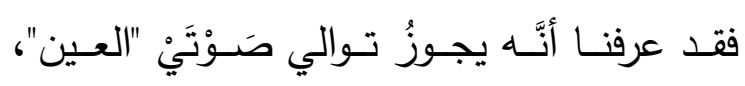
و "الهـاء" في الكلمـة دونَ فصـلِ بينههــا، بشـرطِ

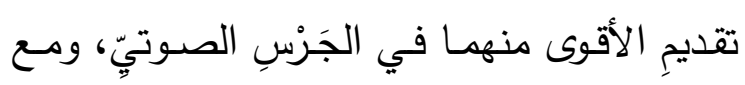
ذلك استكرهَتْ قبائلُ "تميم" النطقَ بهما مُجتمعَيْنِ عندَ إسـكانِ العـين في "مَعْهُم" فأبـدلوا الحـرفَيْنِ

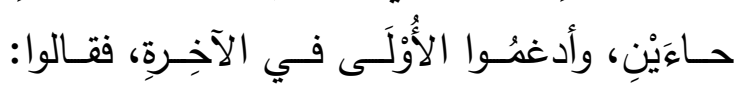

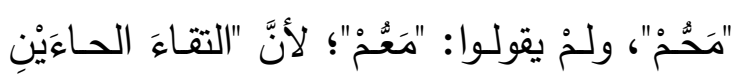

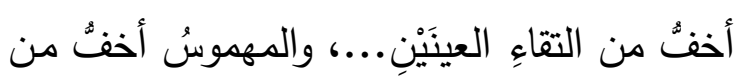

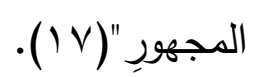
وهكذا، يقصذُ السلوكُ اللغويُّ للتميميّين إلى الإبدالِ الصوتيّ، ثمّ إلى الإدغامِ كوهما ظاهرتان

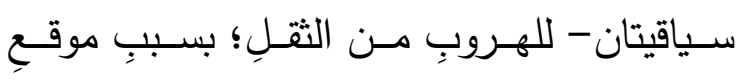

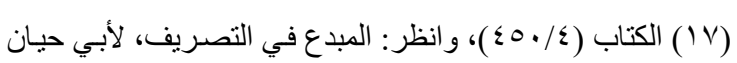

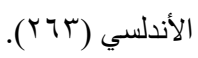




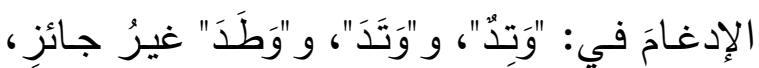

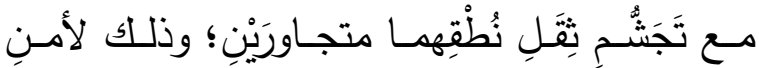

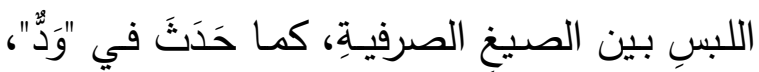

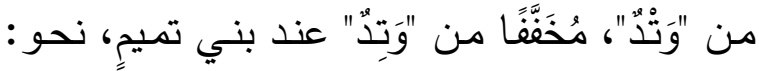

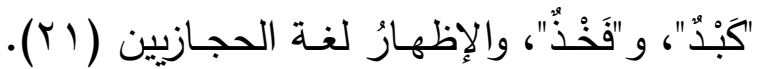

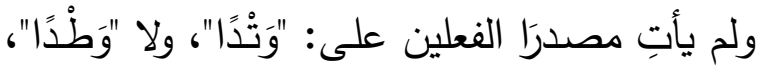

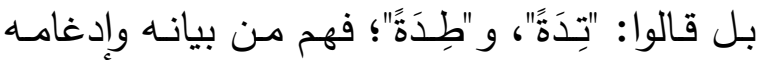

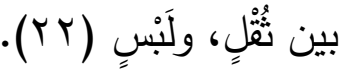

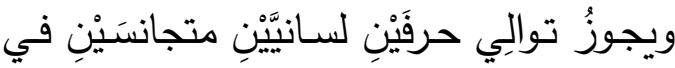
بنيةِ الكلمةِ؛ عندما يكتسبُ أحُُهما صفاتِ الحرفِ

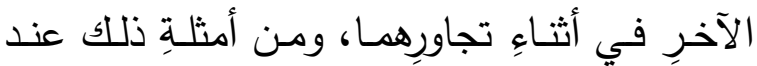
الصرفيين:

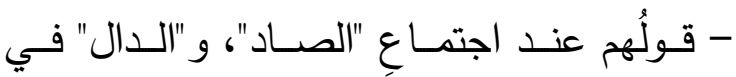

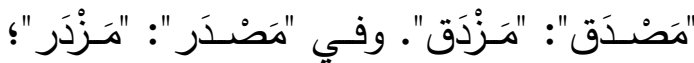

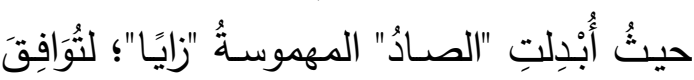

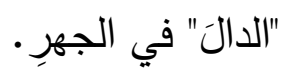

- قولُهم عند اجتماع "الجيم"، و "التاء" في صيغةِ

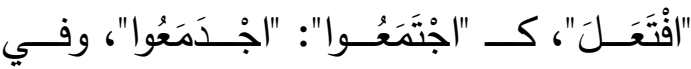

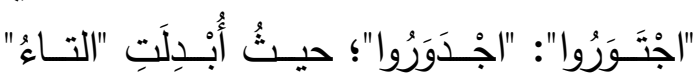

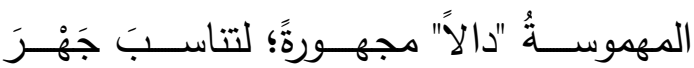

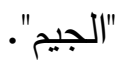

- أجاز الصرفيون تَوالِي الحرفَيْنِ المتقاربَيْنِ، إذا

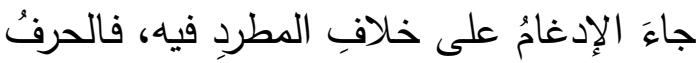

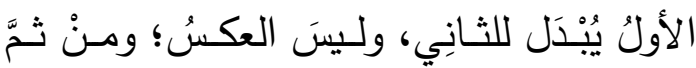
استحسنُوا "اصْطَبَر"، ولم يستحسنُوا "اصَّبَرَ". أو تَرَتَّبَ على الإدغامِ زوائُ الصفِة الصـوتية

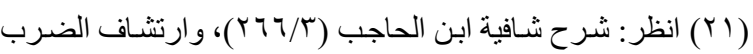

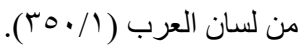

المتتـافراتِ الثقيلـةِة من حروفِ اللسـانِ في بنيـةِ

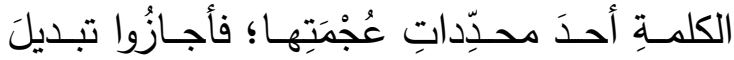

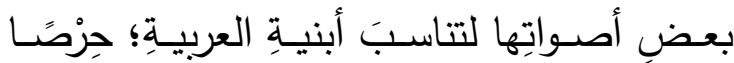

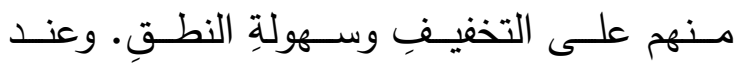

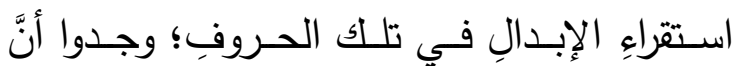

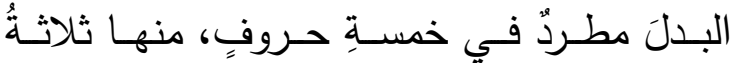
حروفٍ لسانيةٍ، هي: "الكاف، والجيم، والقاف"، وحرفان شفويان هما: "الباء، والفاء". وأنَّهَ غيرُ

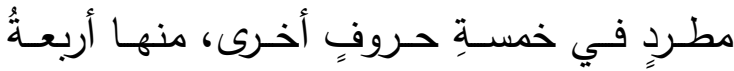
حروفٍ لسـانيةٍ هـي: "السـين، والثـين، والـلام، والراء"، وحرفت حلقيٌّ واحدٌ هو : "العين"(9 (1). غير أنَّ النظامَ اللغويَّ يُجِيزُ توالي حرفَيْنِ

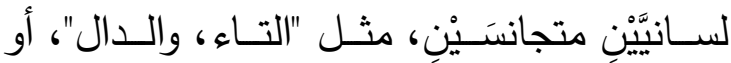
"الطاء، والدال"، كما في الفعلين: "وََتَََ، و "وَطَََ"،

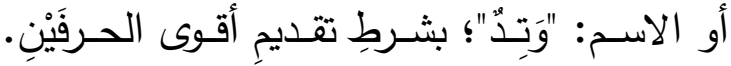
ولـيس مصــرُ قـوة الحـرفِ صـفتَة مـن حيـث الهــس والجهر ، فـ "التـاء" مهموسـة، و "الـدال، والطاء" مجهورتان، وانَّما تَصْدِرُ قوتُه عن تفاعلِ صوتِه مع ما يقارئه من أصواتٍ في المخرج، أو

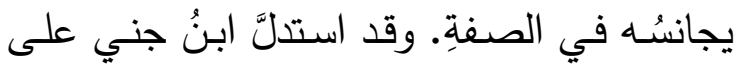

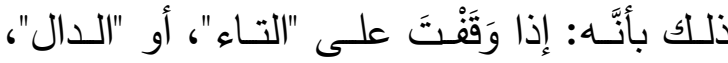

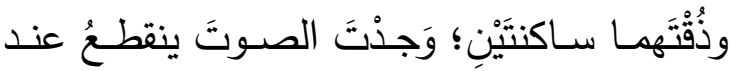

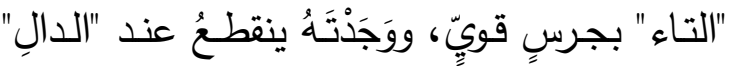
بجرسٍ خفيّ (·•) ورغَمَ أَنَّ النِّظامَ اللغويَّ يُجيزُ إدغامَ الحرفين

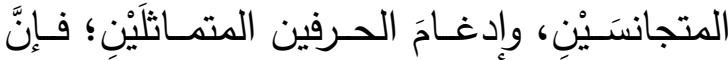

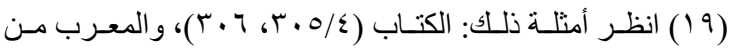

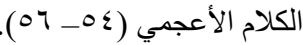

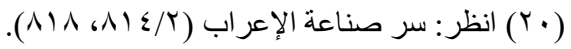


- تَتَحَوَّلُ "التاء" إلىى "طاء"؛ بتأثير صوتِ حرفِ

"القاف" الواقع "فاءً" للكلمةِ، كما في الآراميةِ:

ktr

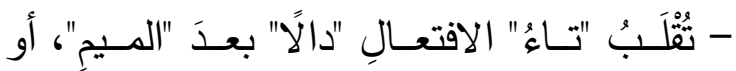

"الجـيم" في الآشـوريةِة، ومثلهـا فـي العربيـةِة:

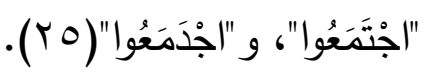

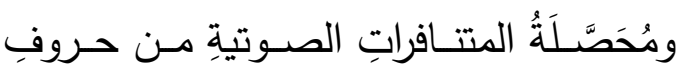

اللسـانِ في بنـايِ الكلمـةِ أنَّ النظـامَ الصـرفيَّ يُجِيزُ وقوعَ التنافِر الصوتيّ؛ بشرطِ تقديمِ الحرفِ الأقوى منها، وذلك عندَ أمنِ اللبسِ بين الصيخ الصرفيةِ،

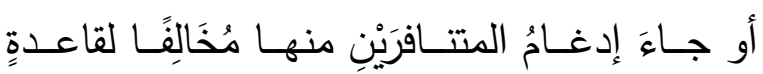
صرفيةٍ مطردةٍ، أو في حالِ تَحَوُّلِ أحدِ المتنافرَيْنِ إلى حرفٍ آخرَ مجانسٍ لهما في الجرسِ والصفةِّ، فُيُعَوِضُض التجنـيسُ الصــوتيُّ التــافرَ اللفظـيَّ في البنيةِ الصرفيةِ.

ب) المتنافراتُ الصوتيةُ في الحروفِ المتماثلةِّ: يُعَـدُّ تجـاورُ حـرفَيْنِ مـن جـنسٍ واحـدٍ مـن

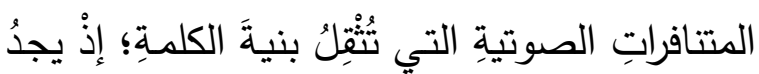
اللسانُ تكلُفًا شديدًا عند الرجوع إلى نفسِ المخرج بعدَ تَحَوُّلهِه عنه. ولذللك يسعى النظامُ الصرفيُّ إلى حلِّ هذه المشكلةِ الصـوتيةِ بإدغام المثلَيْنِ، فيرفحُ

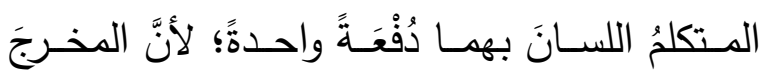
واحدٌ، ولم يفصل بينهما بحركةٍ (T) (Y).

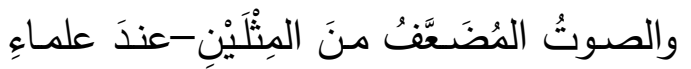

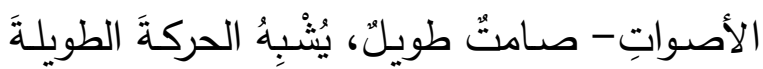

للحرفِ المُدغم؛ ولذللك استحسنُوا "اضْطَرَبَ"،

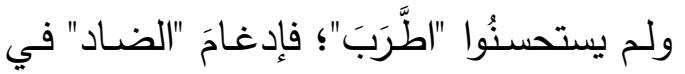

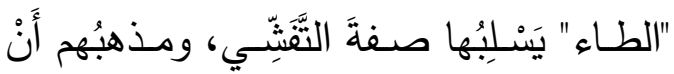

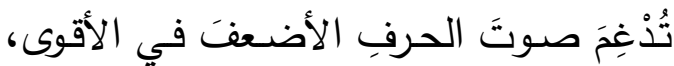

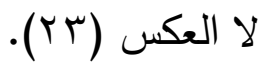

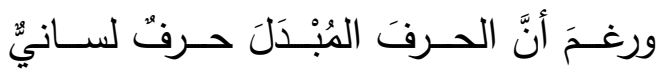

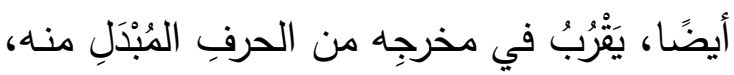
فإنَّ السلوكَ اللغويَّ لبعضِ القبائلِ العربيةِ يَقْصِدُ إلـى اسـتبدالِ التجنـيسِ أو الانسـجامِ الصــتيّ

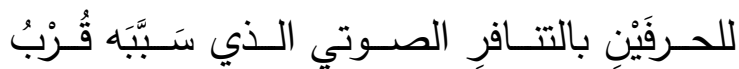

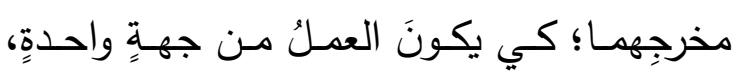
ويجـدُوا بـذلك نوعًا مـن التخفيـفِ فـي نطقِهــا متواليَيْنِ؛ ولذلك أرادوا تَجْنِيسَ أصسواتِ الحروفِ المتنافرةِ في بناعِ الكلمةِ (ع) (ك). وهـذا التجنـيس (التـــثيرُ الصــوتيُّ) بـين حروفِ اللسانِ موجودٌ أيضًا في اللغاتِ السـاميةِ،

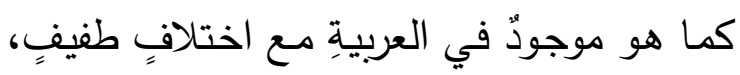
ومن مظاهره:

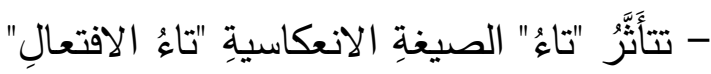
في العربيـةِة، والعبريـةِة، والآراميـةِة بأصــواتِ الصـفيرِ المفخمـةِ أو المجهـورِّة التي تتبـادلُ

\section{معها الأمكنةُ.}

- تََحَََّلُ "التاء" إلىى "دال"؛ بتأثيرِ صوتِ حرفِ

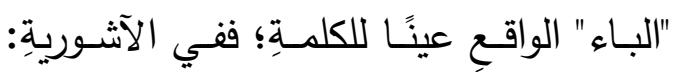
kbt تَتَحَّولُ إلى kbd في الساميةِ الغربيةِة. 
هي الابتداءُ بالساكن-أوَّل المدغَيْنِ-، وهذا

$$
\text { غيرُ جائزٍ في العربيةِ. }
$$

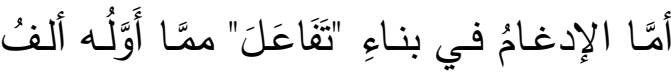

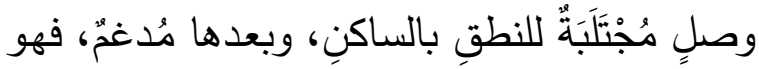

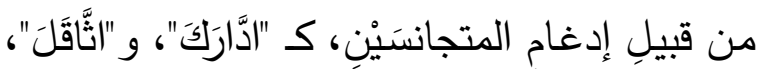

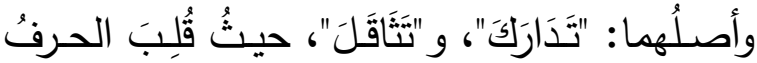

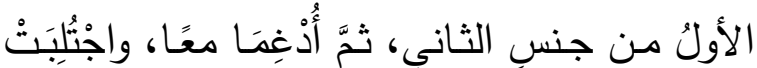
ألفُ الوصل للنطق بأَوَّل المُدغمين الساكن. ب) إلـــاقُ الصـيخ الصــرفية بتجـاورِ حـرفين

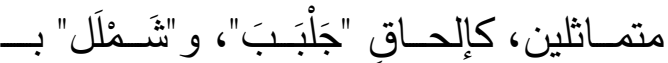
"دَحْرَجَ" في بناءِ الرباعِيّ من الأفعالِ "فَعْلَلَ".

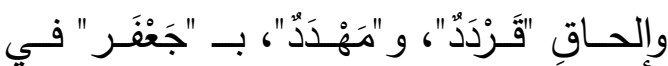

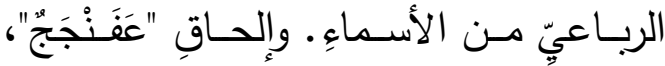

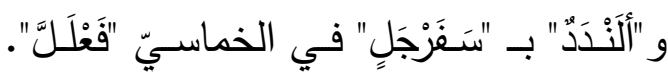
وإدغامُ المثلين في هذه الأبنيةِ يُبْطِلُ غرضَ

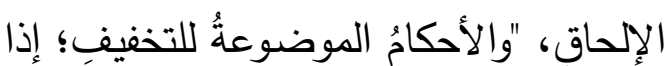

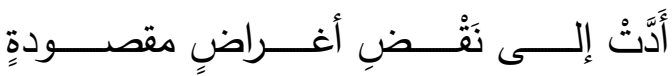

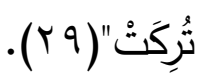

ج) أمنُ اللبسِ بين الصيخ الصرفيةِ، كـ "طَكلِله

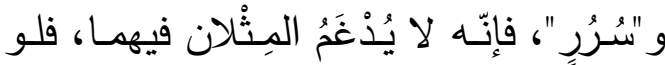

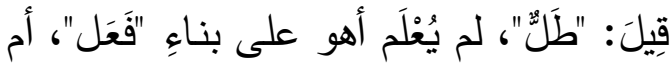

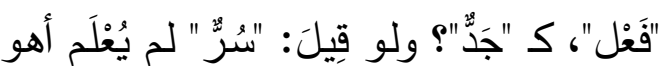

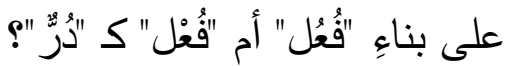
وقدْ أَضْفَى ابنُ جنَي على هذه الحالـِ بُعْدًا صوتيًّا؛ إذْ رأى أنَّ إظهارَ المنتليْنِ في هذه الصيخ كان للفصلِ بينهما بصوتٍ آخرَ، هو صوتُ حركةِ الحرفِ الأولِ منهما؛ ولذلك قَوَتَتُهُ الحركةُ وحَصَّنَتْه

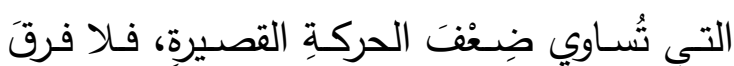

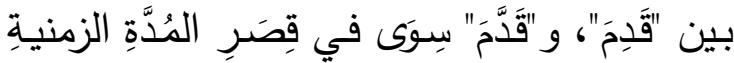

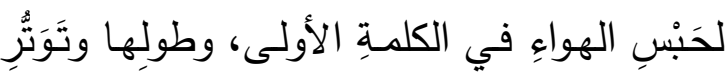
اللسـانِ في المخرج في الكلمـة الثانيـة. ولم يَكُنْ هذا التصـور ببعيدٍ عنِ فكر علمـاء العربيـة، إذِ

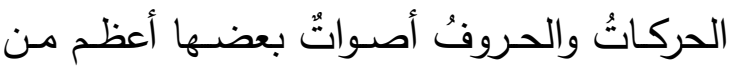

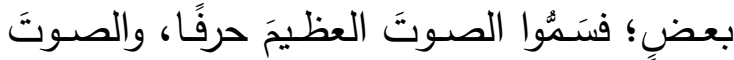
الضعيفَ حركةً، وإنْ كانَا في الحقيقِة شينًا واحدًا (YV)

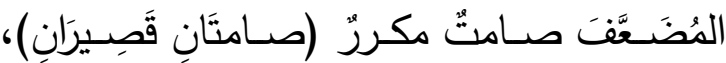
وهذا ما قصدوا إليه عندَ تعريفِهم الإدغامَ (Y^).

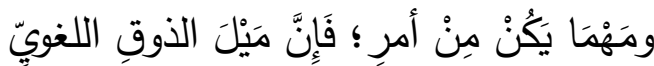

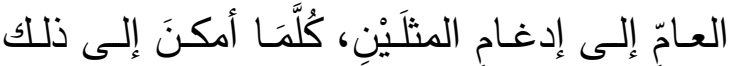

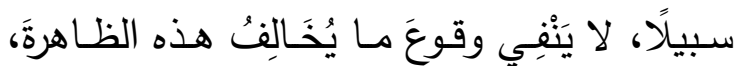

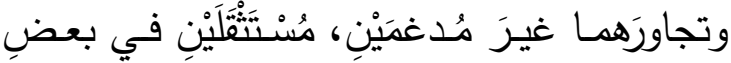
الصيخ؛ لأسبابٍ صوتيةٍة، كالتقاءٍِ الساكتَيْنِ، وهو

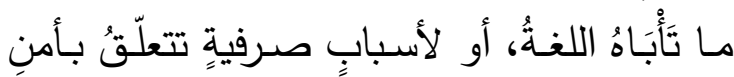
اللبسِ بـين الصـيخ، أو إلحساقِ بعضِـها بـأوزانِ

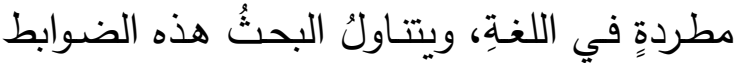
في النقاطِ الآتية: أ) وقَوعُ المثلَيْنِ أصلَيْنِن في صدرِ كلمةِة ثلاثيةِة نحو : "دَدَنْ: اللهو واللعب"، و "بَبَرُ : حيوانُ

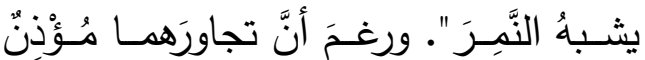

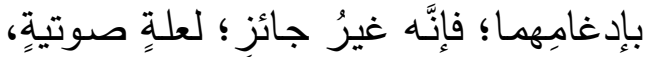

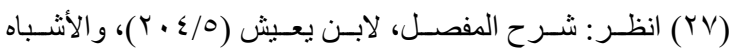

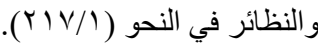
(Y^) (انظر بتصرف: التطور النحوي للغة العربية (rاه)، والمنهج الصــوتي للبنيــة العربيـة، رؤيـة جديــدة فـي الصــرف العربـي 


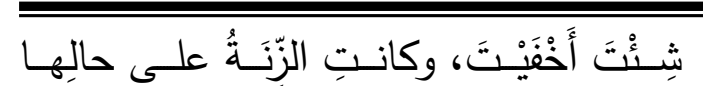

$$
\text { .(1)"... }
$$

وإدغامُ المنَلَيْنِ في هذه الصيغةِ على ثلاثنة

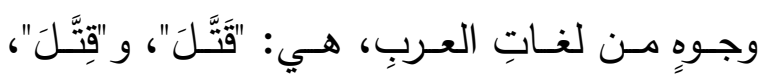

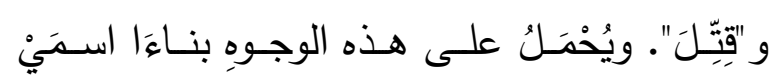
الفاعلِ والمفعولِ، فقد جاءَ في شواذِ القراءِاتِ قولُهـ هُ

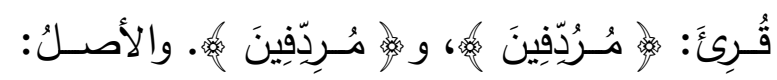

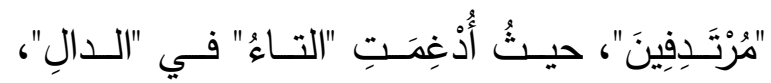

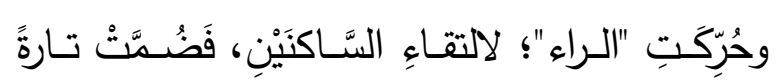

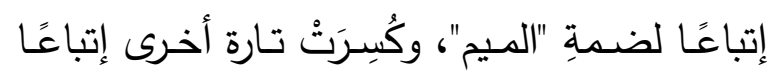

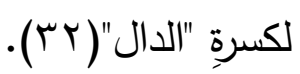
وقد نَصَّ كلٌّ مـن ابنِ عصفورِ الأثبيليّي،

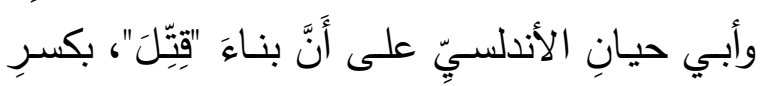

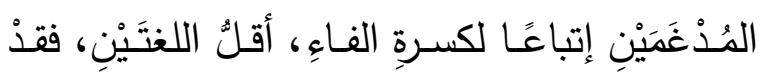

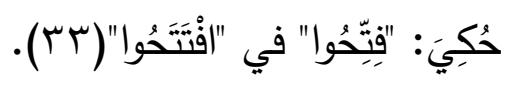

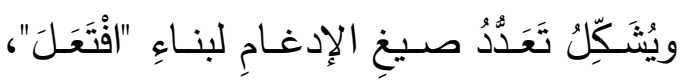

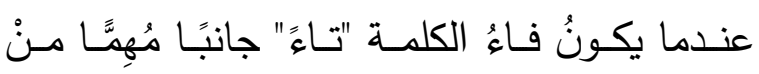

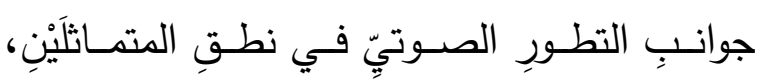

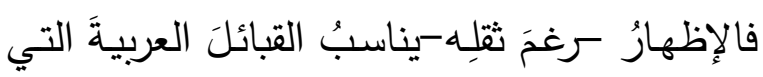

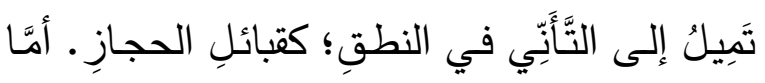

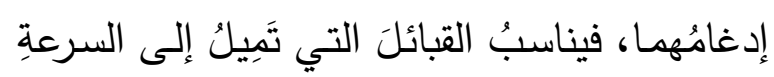

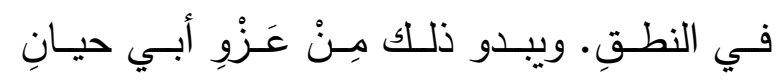

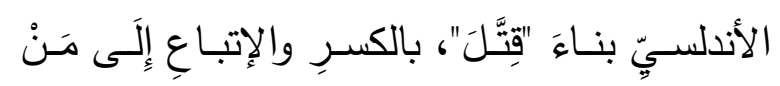

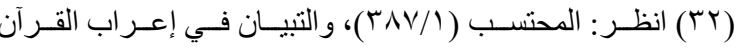

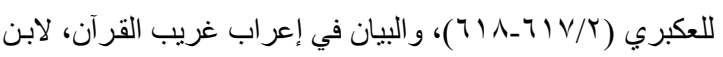

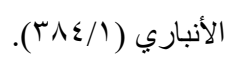

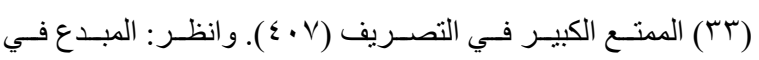

التصريف (Y ( )
مـن الإدغـامِ (•r). أيّْ: أنَّ الثقــلَ لـيس سـبيُّه

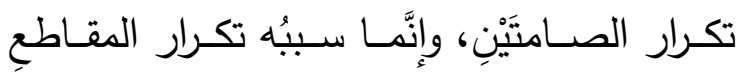

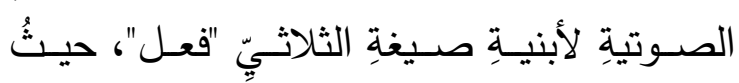

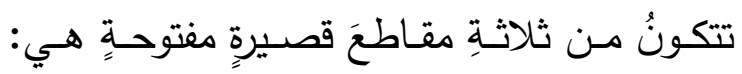
"ص ح/ ص ح/ ص ح"، وسنناقشُ هذه المسألةً

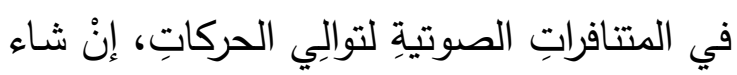
الله.

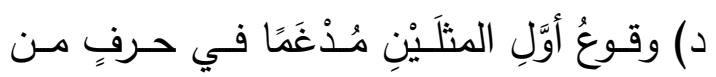

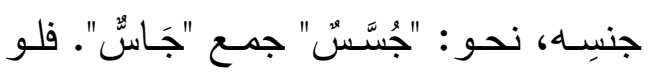

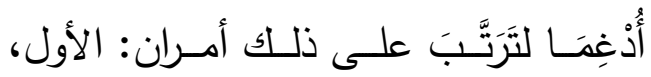

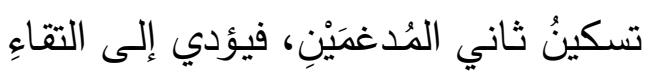

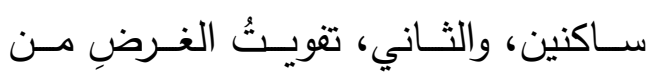

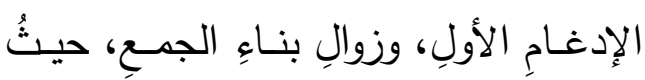

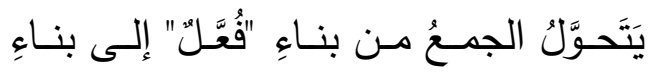

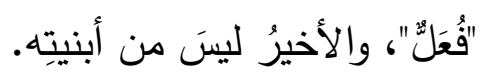

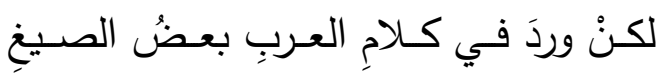

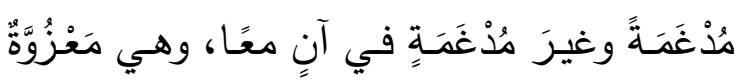

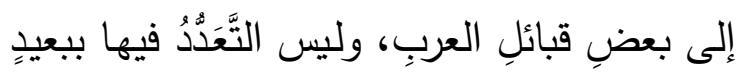

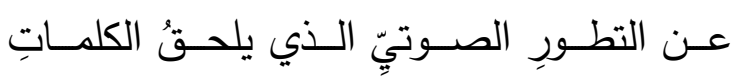

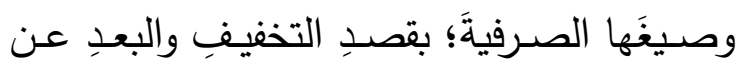

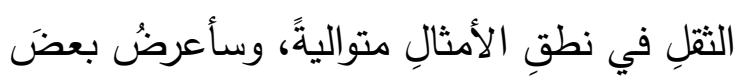

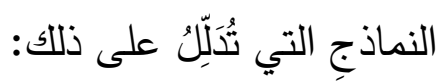

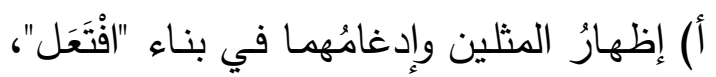

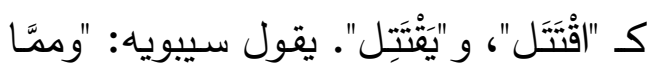

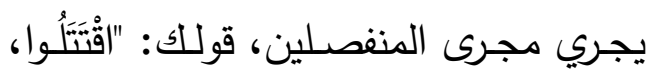

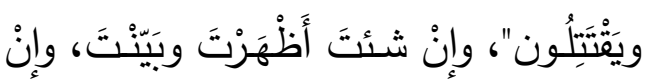




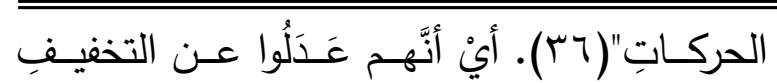

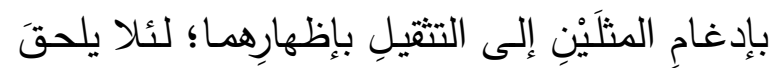

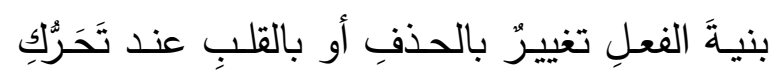

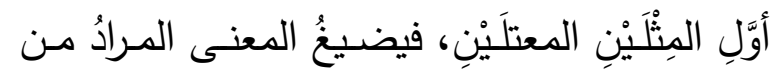

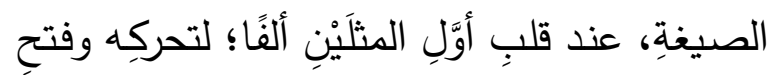

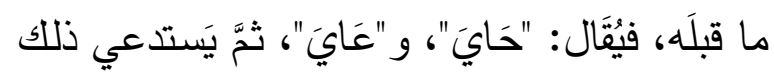
قلب الحرفِ الثاني؛ لتطرفه بعد الألف.

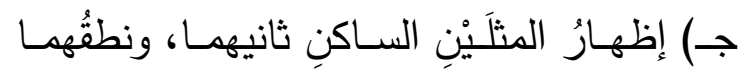

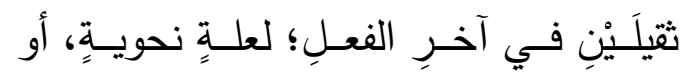

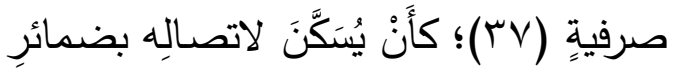

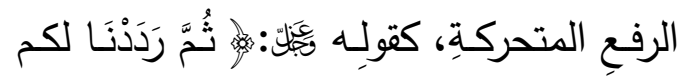

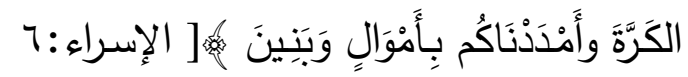

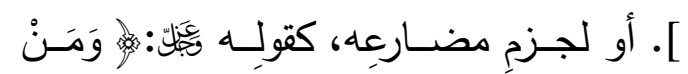

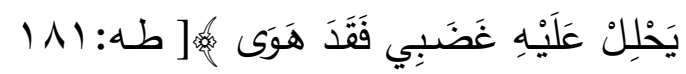

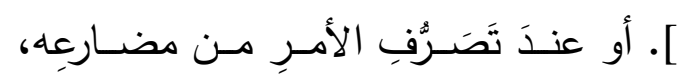

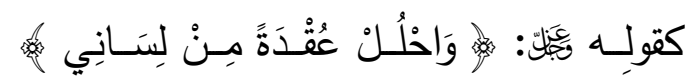

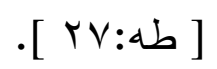

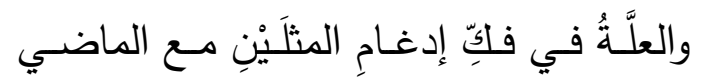

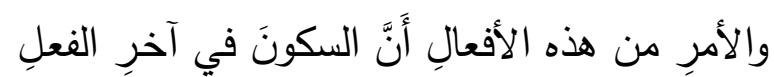

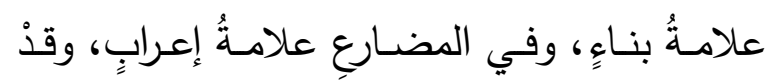

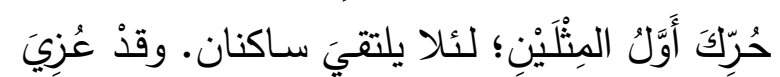

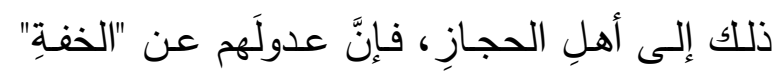

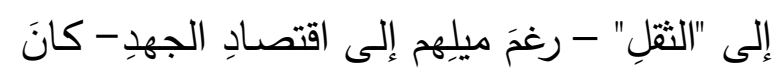

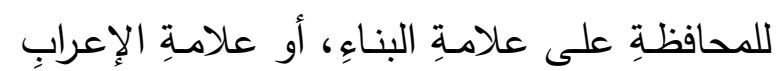
في الفعلِ.

(דَr) شرح الدفصل، لابن يعيش (0.0/0)، و انظر : المنصف شرح التصريف (דr ع).

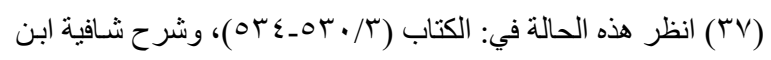

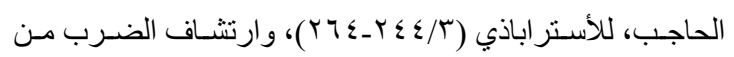

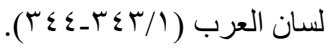

يقولُ في "يَفنَعِل": "يْغِتِعِل"، ويجوزُ كسرُ "القاف"؛

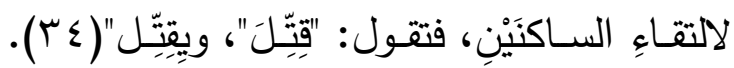

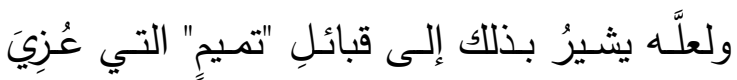
إليها كسرُ حرفِ المضارعةِ. ب) وقوع المِنْلَينِ حَرْفَيْ علةِة في آخرِ الفعلِ،

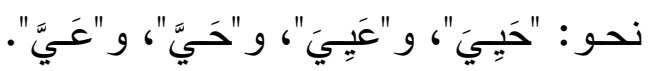

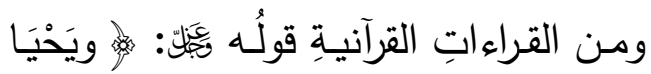

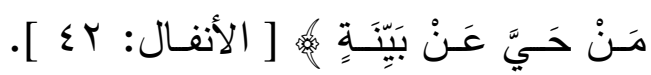

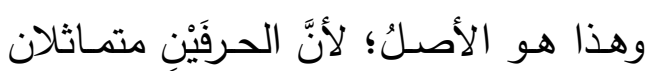

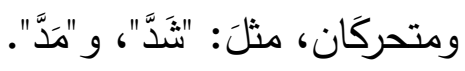

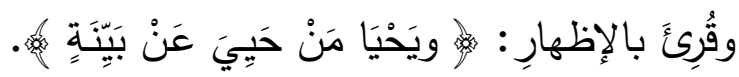
وفي هذه القراءةِ وجهان:

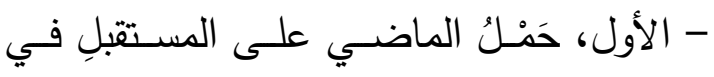
إظهارِ المثلَيْنِ، وهو "يَحْيَا". - والثـاني، أنَّ حركـــةَ الحـــرفين المتمـــاثلَيْنِ

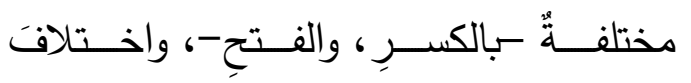
الحركتين كاختلافِ الحرفين؛ فجازَ الإظهارُ،

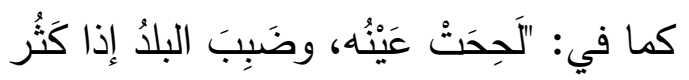

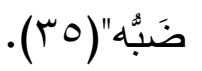

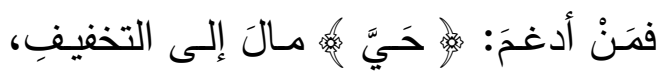

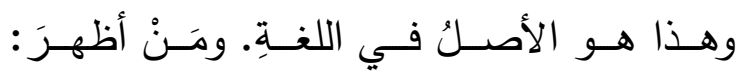

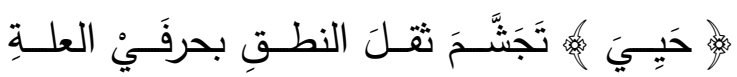

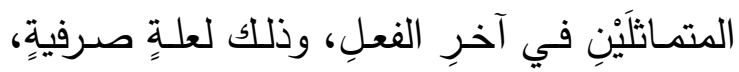

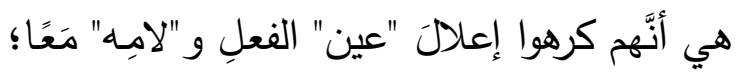

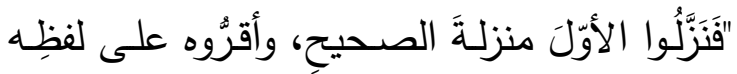

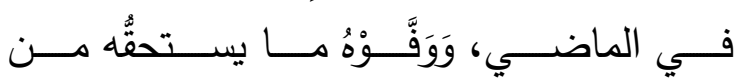

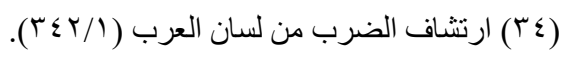

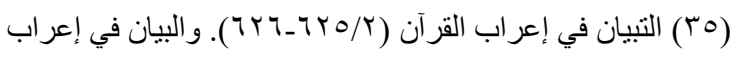

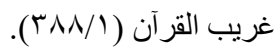


وجوه القراءات القرآنية؛ فلم يكن الإدغاجُ أقلَّ شيوعًا

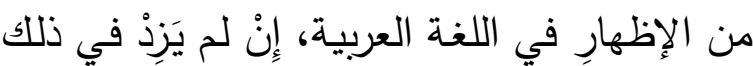

$$
\text { عليه (• ع). }
$$

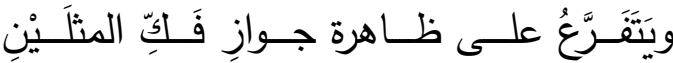

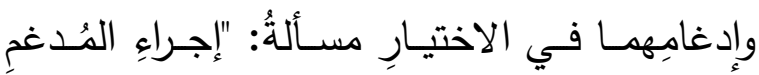

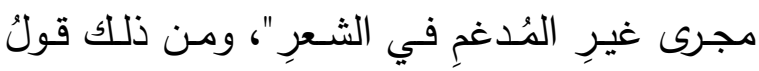
قعنب بنِ أُمِّ صاحبِ

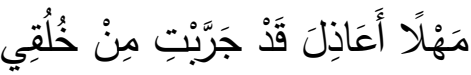

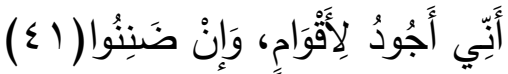

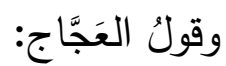

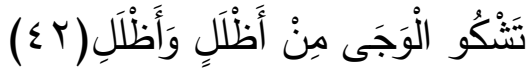

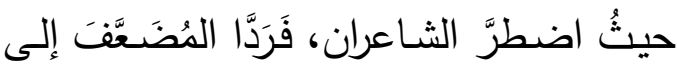

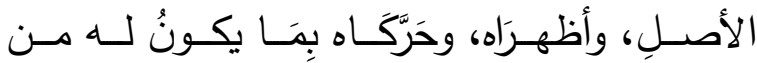

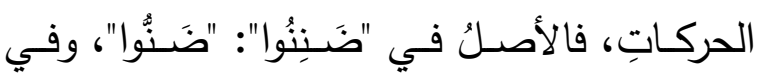

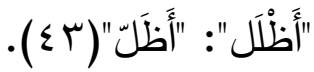
وبعدُ، فقد كانت هذه أمثلةً قصدتُ إليها في سبيل الاستـدلالِ على ظـاهرِ جوازِ وقوع التتافِر

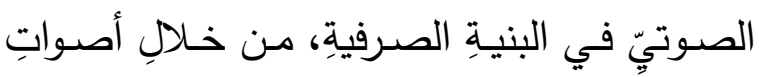
الحروفِ المتجانسـةِ، وأصـواتِ الحروفِ المتماثلـةِِِِ

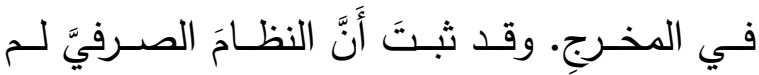
يَرفضْها رفضًا تامًَا؛ فهي جزيٌ منَ رصيدِه اللغويّة،

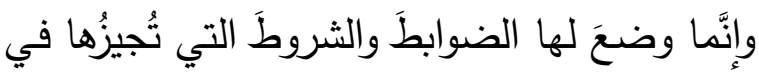

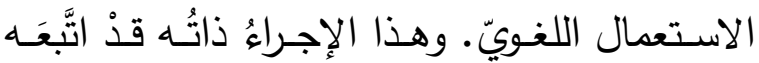

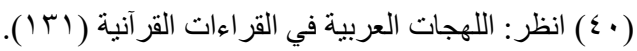

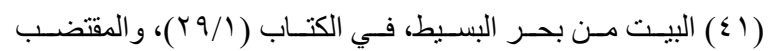
(r०s/T)

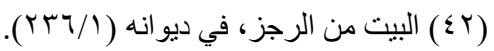

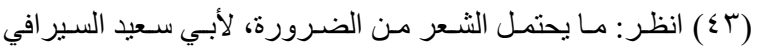

ولكنْ سَـلَكَتْ بعضُ القبائلِلِ العربيـةِ التي

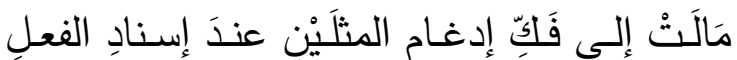
المضعفِ الثلاثيّة، مكسورِ "العينِِ" إلى ضمائرِ

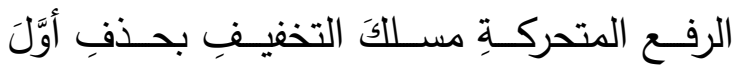

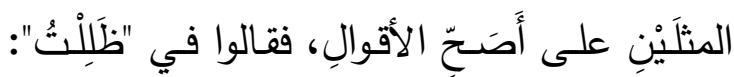

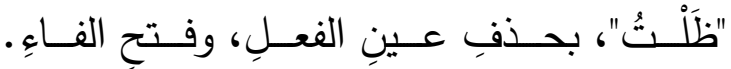

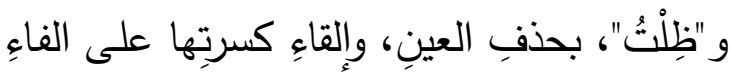

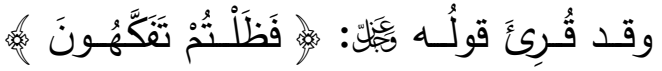
[ الواقعـة:70 ] بالوجوهِ الثلاثدة: فعلى الأصلِِ:

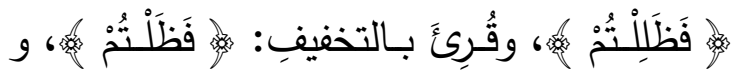

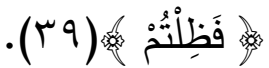
أمَّا إدغامُ المثلَيْنِ في هذه الحالاتِ؛ فقد وردَ

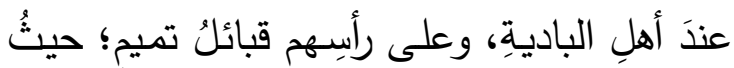

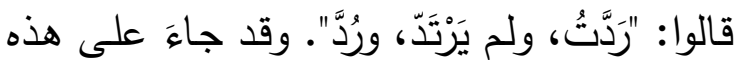

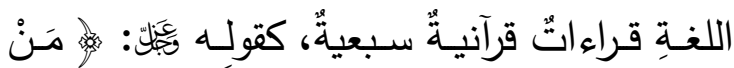

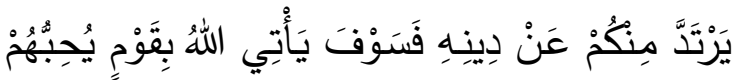

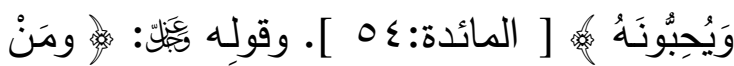

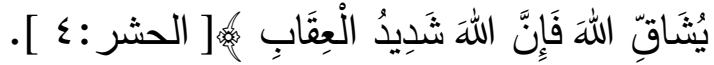

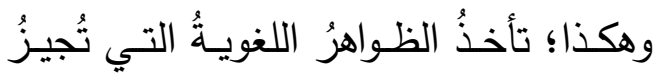
وقوعَ التنافِر الصوتيّ في البنيةِ الصرفيةِ بضوابطَ

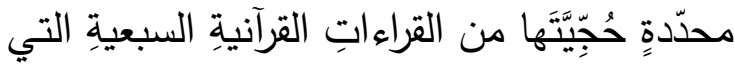

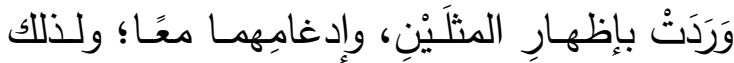
ذهبَ الدكتور عبده الراجحي إلى شهرة القراءةِ

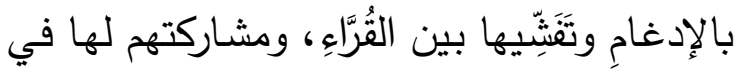

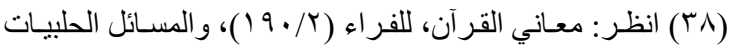
(1 (1 - - 149$)$

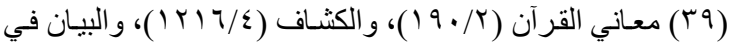
غريب إعراب القرآن (1)/r (§). 
- الأولى،عند سكونهِا، وفتح مـا قبلهما، نحوَ:

$$
\text { "تَوْرِ "، و بَيَيْتُ". }
$$

- والثانيــة، عنــدما يتحركــان بحركـةِة قصــيرةٍ،

$$
\text { نحوَ :"وُوضِحَ"، و "يَسُرَ ". }
$$

وفي هـاتين الحـالتين يُعَامَلُ هذان الصـوتان

باعتبارَيْنِ: "الأَوَّل، أنَّهما نصفُ حركةٍ من الناحيةٍ

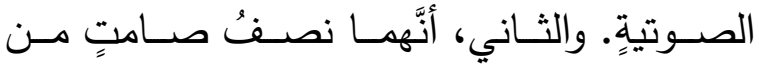

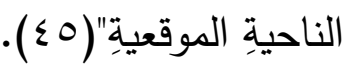

أمـا "الألف مـن الناحيـة الصـوتيةِ فـلا تكونُ

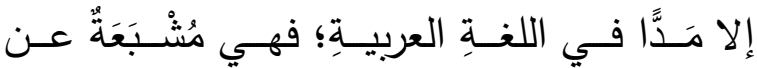
الفتحـــة القصــيرة التــي تتاســـُها. غيــرَ أنَّهـــا

مـن الناحيــةِ الصــرفيةِ الاشــتقاقيةِ منقلبـةُة عـن

أصــلِ هـــو "الــواو"، أو "اليــاء"، فأصــلُ الفعـلِ

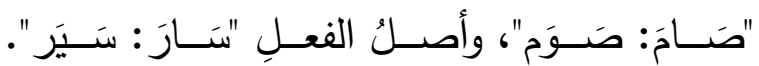
ورغـم اتفـاق الفعـلِ وأصــله في البنـاء الصــــي "فَعَلَ"؛ لاعتمادِ الميزانِ الصرفيّ على فكرةِ الأصلِ أو جـذرِ الكلمـةِ؛ فإنهمــا مختلفــان مـن منظــورِ

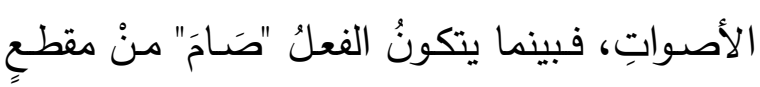

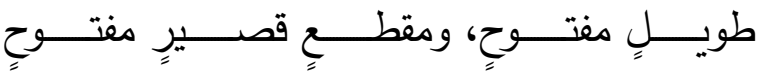
( ص ح ح/ ص ح )؛؛ يتكونُ"صَـوَمَ" مـنْ ثلاثــة مقاطعَ قصيرةٍ مفتوحة( ص ح/ ص ح/ ص ح )؛ ولذلك يجبُ الحذرُ عندَ التعاملِ مـع حروفِ المَدِّ في بنيةِ الكلمةِِ؛ لاعتباراتٍ صوتيةٍ تَتَعَلَّقُ بوصفِ

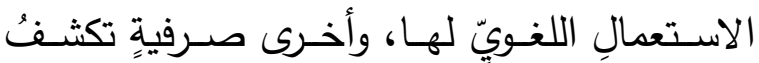

الجوانبَ المعياريةَ فيها (7ء).

(0) المنهج الصوتي للبنية العربية، رؤية جديدة في الصرف العربي

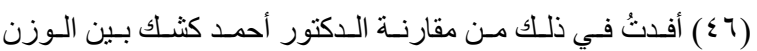
الصرفي والوزن المقطعي في كتابه: من وظائف الصوت اللغوي، محاولة لفهم صرفي ونحوي ودلالي (ro).
الصـرفيون مـع المتــافراتِ الصـوتيةِ في تـوالي الحركاتِ، وهذا موضوعُ المبحثِ الثاني. المبحث الثاني: المتنـافراتُ الصـوتيةُ في توالِي الحركاتِ

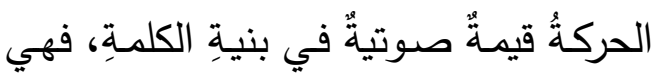

تتفاعــلُ وأصـــوات الحــروفِ "الصــــوامت"، أو الحركاتِ "الصوائت" المجاورةِ لها، فتُقَّوِي الحرفَ وتُحَمِّنـة مسنَ الإدغـام أو الإبـدالِ، وتُحَدِّدُ المـدةَّ

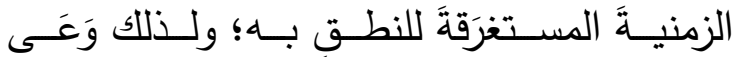
الصـرفيون العـربُ العلاقـةَ الصـوتيةَ الكَمَّيَّةَ بـين الحركاتِ في النظـامِ المقطعِّ للكلمـةِ، إذْ قَسَّموا الحركاتِ إلى حركاتٍ قصيرةٍ، وأخرى طويلةٍ أمـا

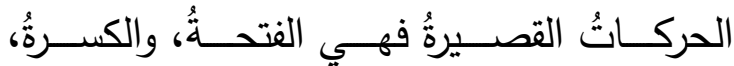
والضـةُُ، والحركاتُ الطويلـةُ فهي حروفُ المدِّ، الألفُ، والياءُ، والواو • يقولُ ابنُ جني في ذلك: "الحركـاتُ أبعـاضُ حـروفِ المـدِّ واللينـ...، وقد

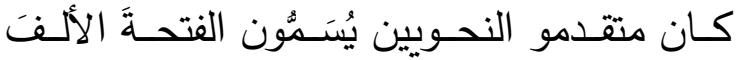
الصـغيرةَ، والكسرةَ الياءَ الصـغيرةَ، والضمةَ الواوَ

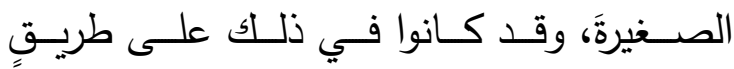
مستقيمةٍة"(ع §) .

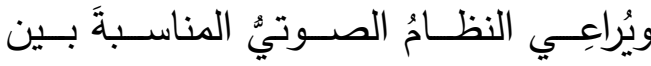
الحركاتِ ومجانسةِ بعضِها البعضَ. وعلى أساسِ ذلك تكـونُ حـروفُ المَدِّد حركـاتٍ "صـائتةٍة"؛ إذا

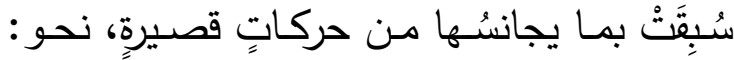

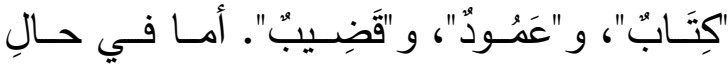
غيـابِ تلـك المناسـبةِ الصـوتيةِ عنهـا؛ فتصـير حروفًا صسامتةً أو أشباة حركاتٍ، وهذا لا يكونُ إلَّا مع صوتَيْ "الواو"، و "الياء"، في حالتين هما: 


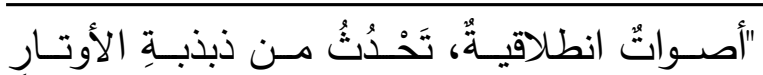
الصوتيةِ عندَ مرورِ الهواءِ بها، وليسَ للفِّ من دورِ

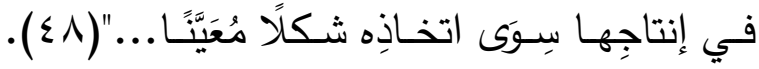
ومع تتابعِ أصواتِ الحركاتِ، دونَ اعتراضٍ للهواءِ

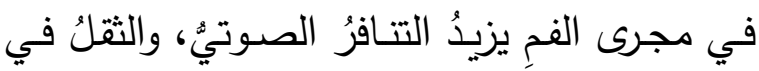

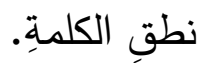

وعندَ استقراءِ كلام العربِ وُجْدَ أنَّ المتنافراتِ

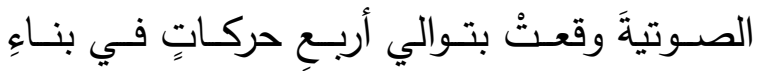

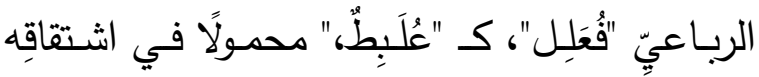

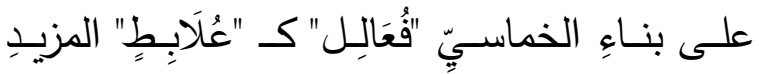

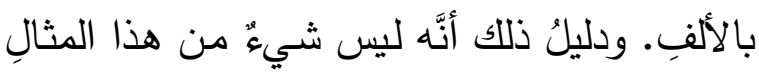

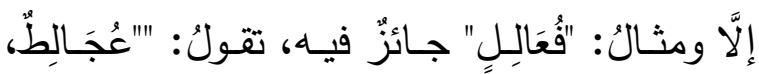

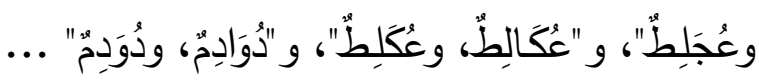

وقـذ ربطَ الصـرفيون العـربُ بين الصـيغتَيْنِ

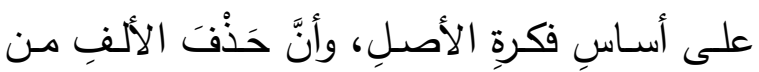

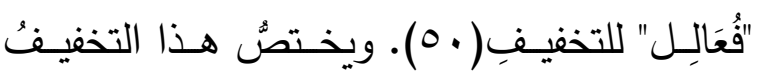

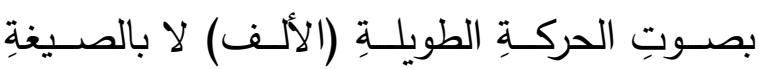
الصرفيةِ؛؛ إذْ إنَّ الثقلَ الحادثَ من توالي الحركاتِ

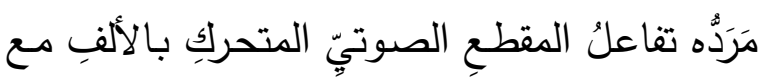

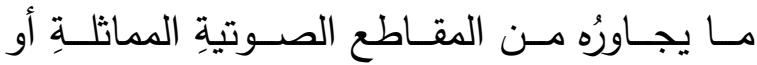

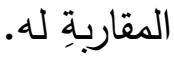

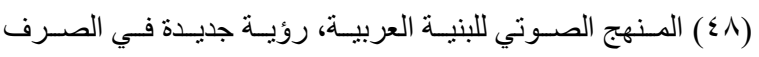

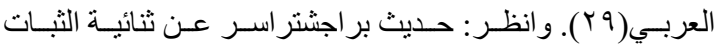

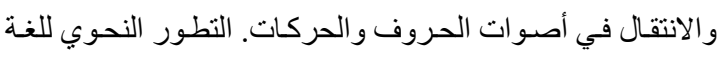

العربية (00_070).

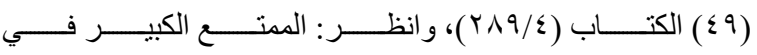

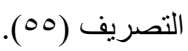
(0) انظر: المنع الكبير في التصريف (00)، وشرح المفصل، لابن

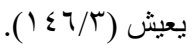

ومهما يَكُنْ من خلافٍ حولَ توصيفِ بعض

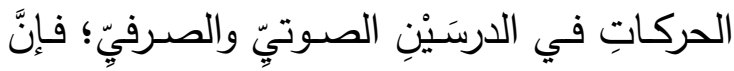

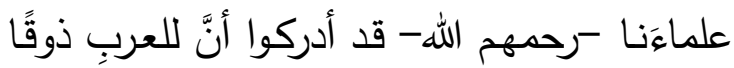
لغويًا في استعمالِ الحركاتِ، يقومُ على المناسبةِ

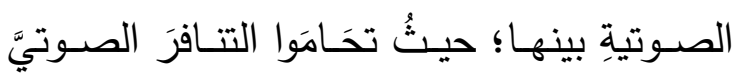

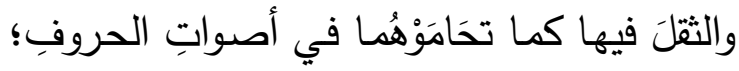

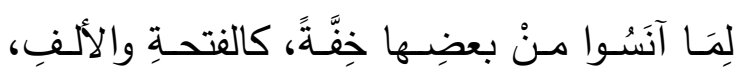

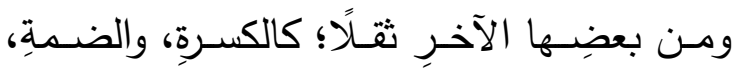

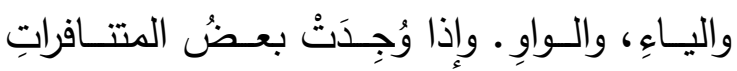

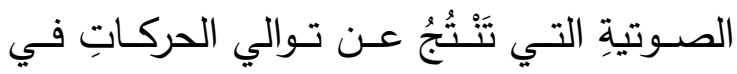

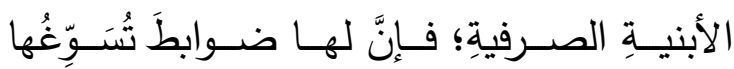

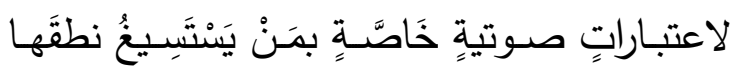

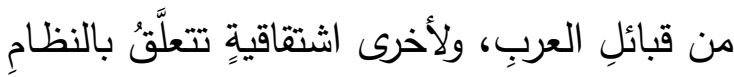

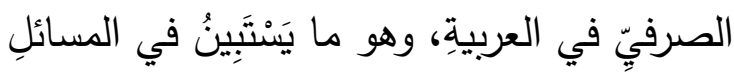
الآتية:

() التََّّالِي الكَمِّيُّ للحركاتِ في (فُعَلِل، وفُفَعالِل):

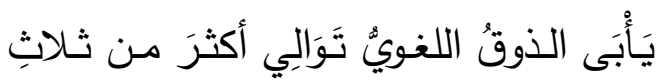

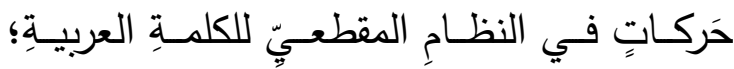

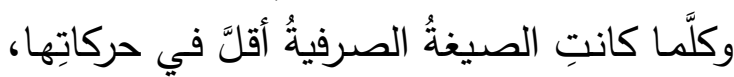

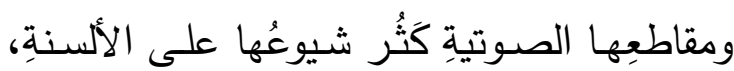

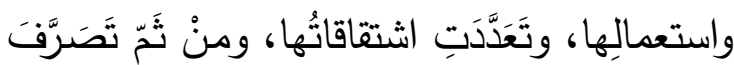

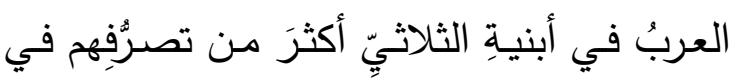

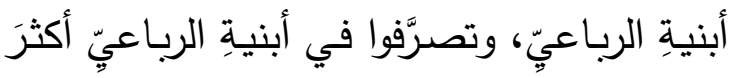

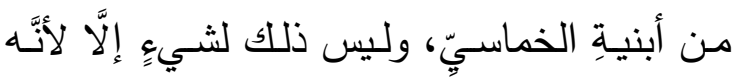

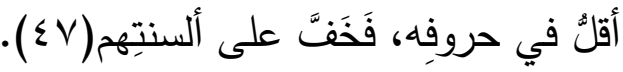

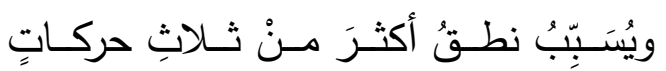

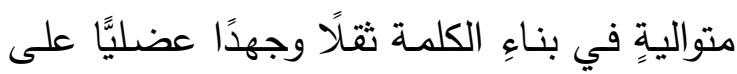
جهازٍ النطقِ والتفسيرُ العلميُّ لذلك أنَّ الحركاتِ

( ) انظر : المتع الكبير في التصريف (†ه). 
- الأول، اختيارُ أخفِّ الحركاتِ (الفتحةِ)؛ لتكونَ

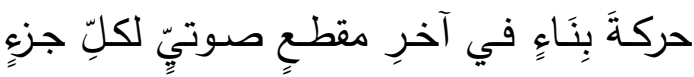
مـن العـددَيْنِ المـركبَيْنِ؛ لتتِّـقِ مـع حركـاتِ المقاطع الأُخْرَى فيكونَ التماثلُ الحركيُّ نوعًا مـن التخفيفِ عندما يعملُ جهازُ النطقي في اتجـاهِ واحدٍ فـي أثثـاءِ التصـويتِ بالحركـاتِ

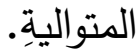

- والثـاني، فَصْــُ الحركـاتِ الخفيفــة المتماثلــة

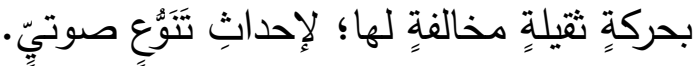
فقبائلُ "تميم" تكسرُ "الثَّين" في "عَشَرَ"؛ طلبًا للخِفَّةِة، وهذا يتفقُ مـع عـاداتِهم النطقيـةِ التـي تَمِيلُ إلىى الكسرِ ، دونَ الفتح. - والثالث، الفصلُ بين المتحركاتِ بسـاكنٍ، كأَنْ تُسَكَّنُ "العينُّ"، أو "الشينُ" في "عَشَرَ"، فيُقِال: "أَحَدَ عْشَرَ"، أو "أَحَدَ عَشْرَ"، وهذا معزوٌِّ لقبائلِ

$$
\text { الحجازِ (ror). }
$$

وينصُُ بروكلمان على أنَّ الحركاتِ في العددِ

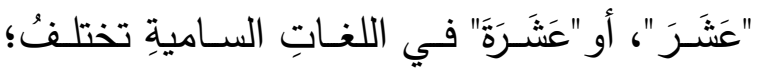
حسب إفرادِهـا وتركيبها مـع عددٍ آخرَ، فالسُريانية

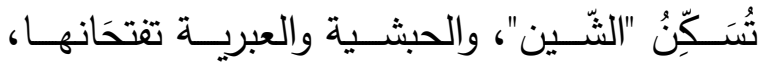

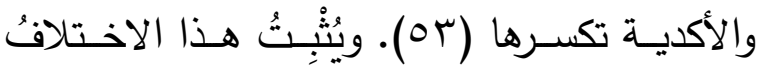

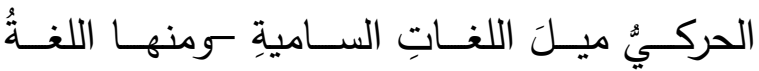
العربيةُُ- إلى ضبطِ توالِي أكثر من أربع حركاتٍ في المقاطع الصوتيةِ للأعدادِ المركبةِة. غيرَ أنَّهـ لا

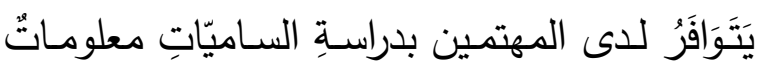

ror) انظـر : شـرح كافيـة لابـن الحاجب، لرضـي الدين الأستر اباذي

( $(490 / \%)$
أمَّـا مــن منظــور التحليـلِ الصـرفيّ؛ فـإنّ

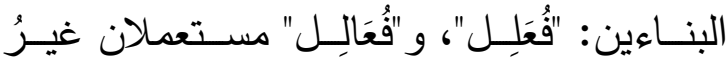
مهمليني، وإحـدى الصـيغتين مجـردةُ، والأخـرى مزيدةٌ. ولا خلافت بينهما إلَّا من الناحيةِ الصوتيةِ

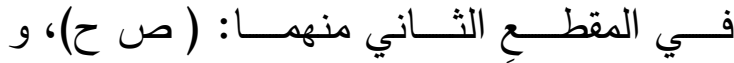
( ص ح ح )، فمجـالْ ظهـورِ المقطـحِ الطويـلِ المفتـوح ( ص ح ح ح ) فـي الكلمـاتِ المزيــدةِ والصيخ الاشتقاقيةِ، وعند إعلالِ بعضِ أصواتِها، ويختفي تمامًا من كافَّةِ أبنيةِ الصيخِ المجردةِ، في الصِي الوصـلِ أو الوقفِ (10). كمـا أنَّ المُدَّةَ الزمنيـةَ لنطـقِ المقطــِع الطويـلِ المفتـوحِ ( ص ح ح )

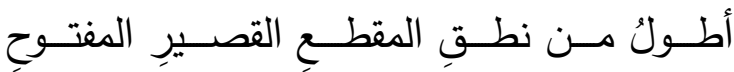
( ص ح )، على أساسِ أنَّ "الألفَ" حركةٌ طويلةٌ للفتحةِ القصيرة. ويقعُ التماثلُ الحركيُّ المَنْفُورُ منه بأكثر من

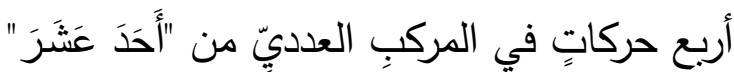
إلِى "تِنْعَةََ عَشَرَ "، وهو في حكمِ الكلمـةِ الواحدةِ عند الصـرفيين العـربٍ. ويختلفتُ كَمٌُ الحركـاتِ

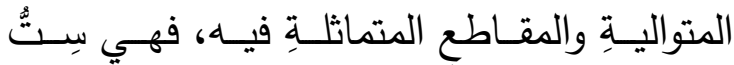
حركـاتٍ فـي "أَحَدَ عَشَـرَ "، ومقاطعُهــا قصــيرةٌ

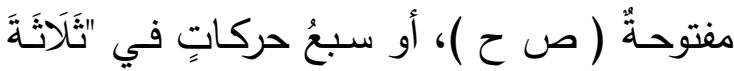

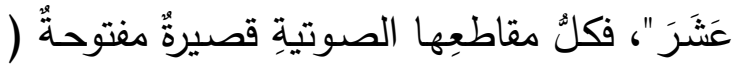
ص ح ) مـا عـدَا المقطـحَ الثانيَ ، فهـو مقطـحُ

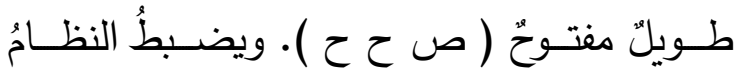
الصـرفيُّ تـواليَ هـذا الكَمِّ مـن الحركـاتِ بثلاثـة إجراءاتٍ، هي: 
ومـا يَعْنينَا من هذه اللغناتِ-بصرفِ النظر

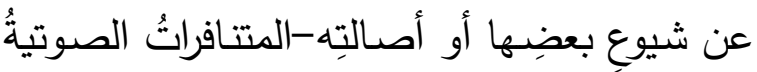

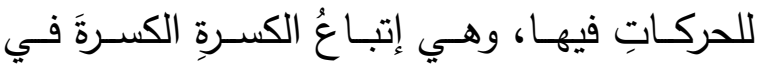

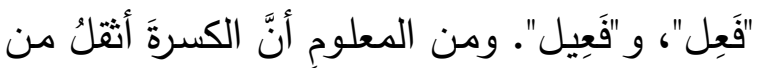

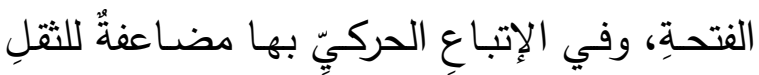

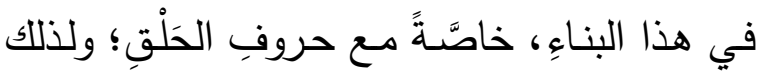

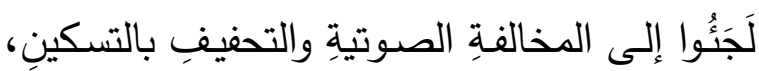
بعد إتباع "الفاء" للعينِ في كسرِها، فقالوا : "فِعْل". وقذْ علَّل الصرفيون العربُ قبولَ النطقِ بحركتَّنِن

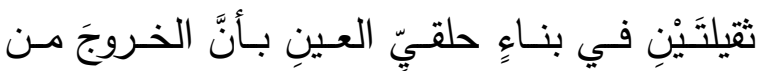

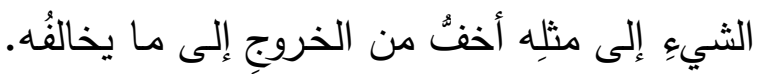

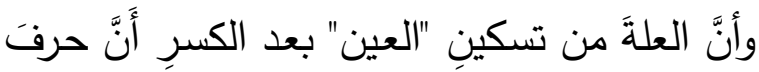

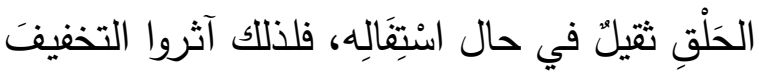

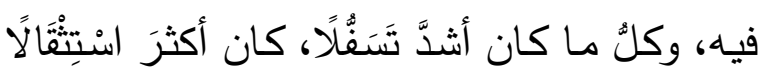

وقد وضحَ أبو حيانِ الأندلسي ثلاثةَ ضوابطً

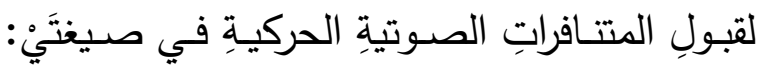
"فَعِل"، و "فَفَيليل"، وهي:

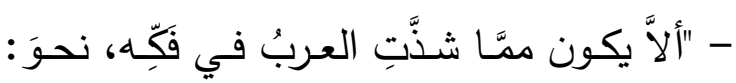

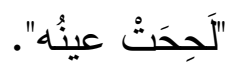

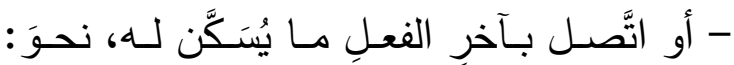

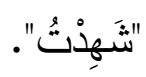

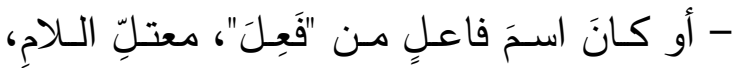

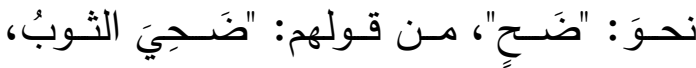

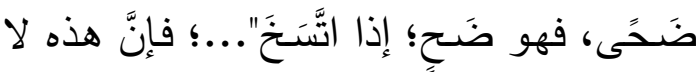

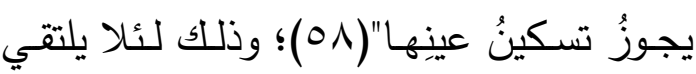
ساكنان في الكلمةِ، وهو ممَّا تَأَباهُ اللغةُّ.

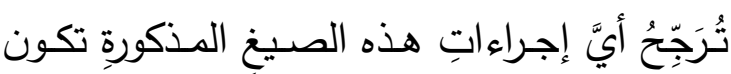
أصلًا للتغييراتِ الصوتيةِ الأخرى.

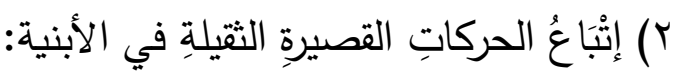

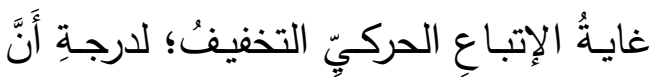

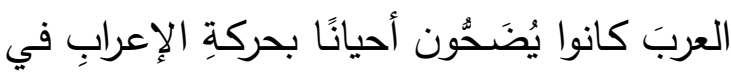

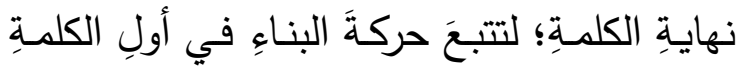
التي بعدَها، وحُمِلَ على ذللك قراءةُ إبراهيَّ بنِ

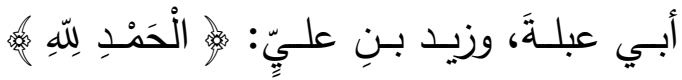

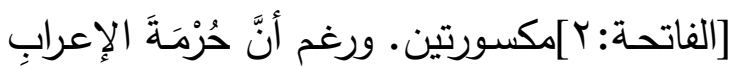

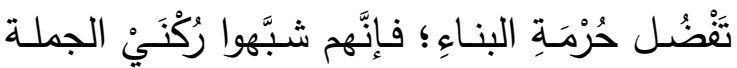
الاسمية بالجزِ الواحدِ؛ فجَرَبِ الجملةُ في الإتباع مجرى "إِلٍِ"، و و"إِلٍٍِ"( ؟ ه). أ) الإتباعُ الحركيُّ في بناء (فعل) الحَلْقِيّ العينِي:

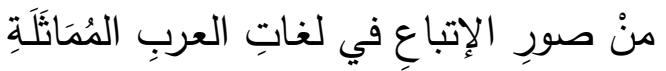

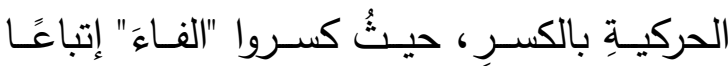

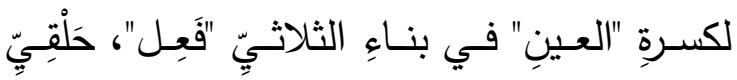

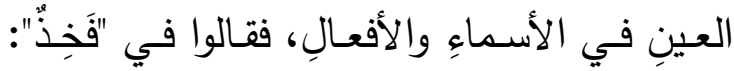

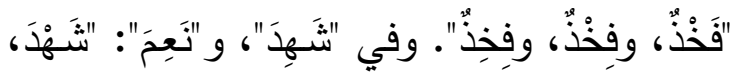

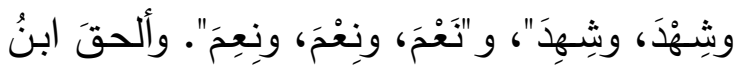

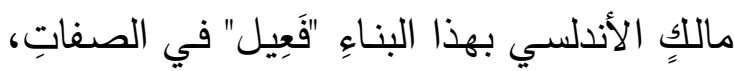

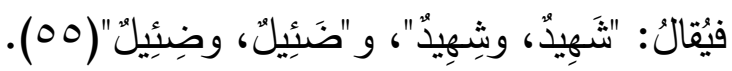

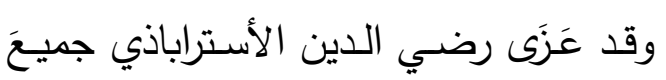

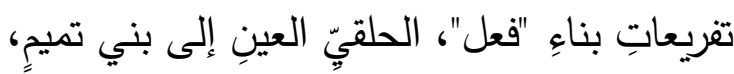

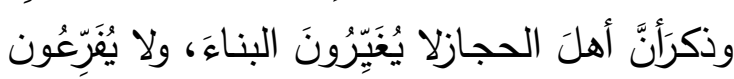

(0) انظـر بتصـرف: المحتسب في تبيـين وجوه شـواذ القرعات

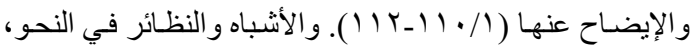

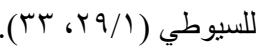

(00) انظر : شرح التسهيل (T/ T). (07) انظر : شرح شافية ابن الحاجب (1/ ( ع). 


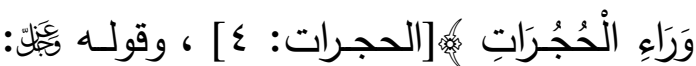

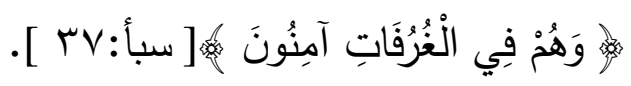

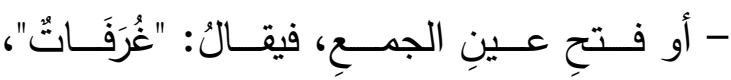

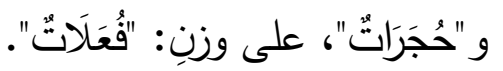

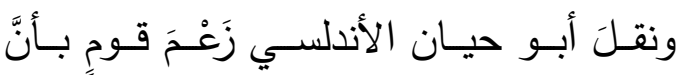

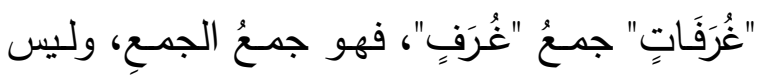

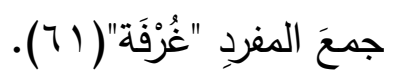

ولم يكنِ الإتباعُ الحركيُ في أبنيةِ جمع الاسمِ لئح

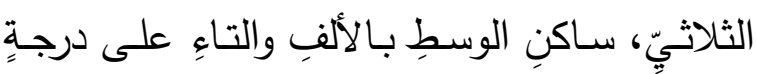

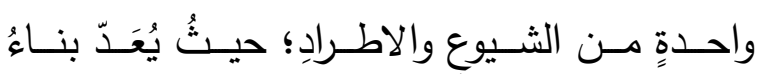

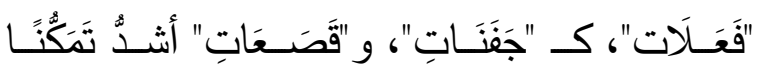

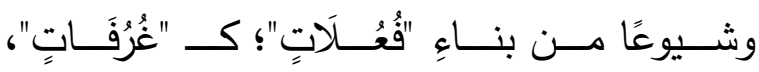

$$
\text { و "ظُلُمَتاتِ"، لأمرين: }
$$

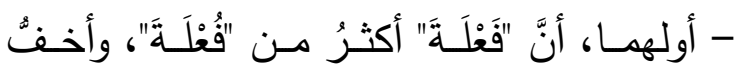

$$
\text { لفظًا، فكان التوسّحُ فيه أكثرَ. }
$$

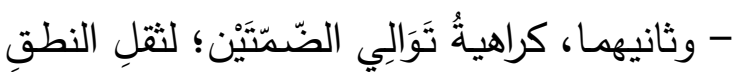

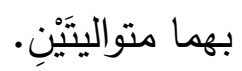

هـذا إذا كـانَ الأمـرُ متعلقَّا بموازنــة الثقتيـلِ

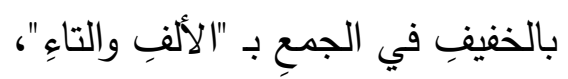

وعندمَا قارنَ الصـرفيون بينَ الثقيـلِ والأثقلِ

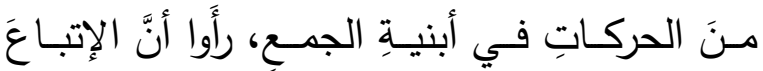

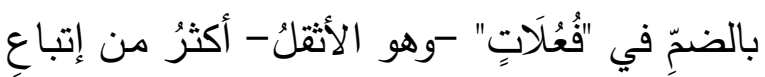

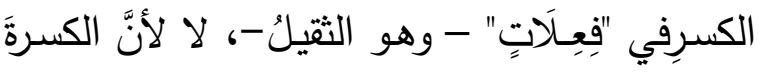

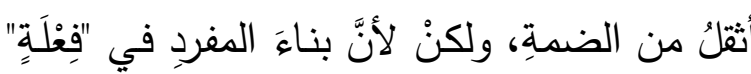

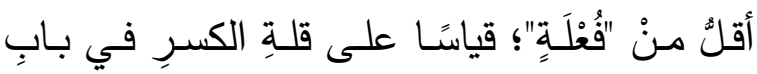

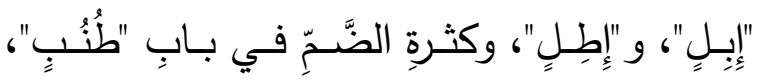

ب) الإتباعُ الحركيُّ في جمـِ الثلاثيّة، سـاكنِ الوسطِ بالألفِِ والتاءِ:

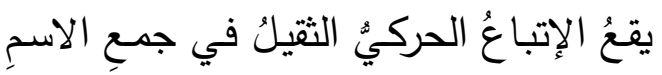

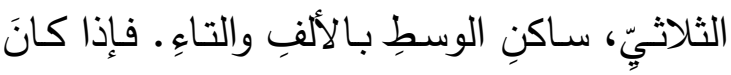

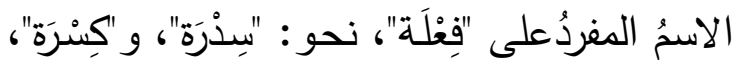
فيجوزُ في جمعِه المغردئ

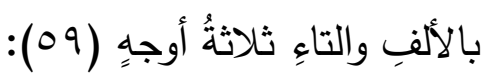

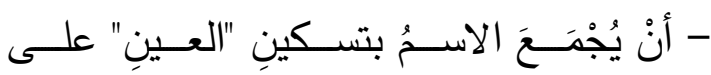

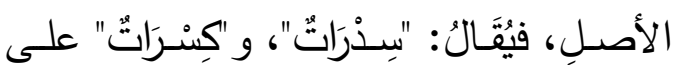

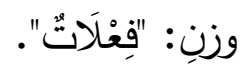

- أو كسرِ عينِ الجهـع؛ إتباعًا لكسرةِ "الفاءِ"،

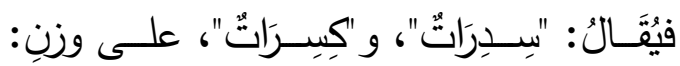

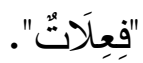

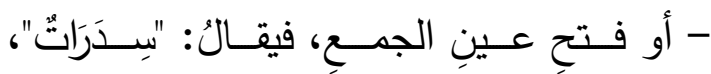
و "كِسَرَاتُّ"، على وزنِّ: "فِعَلَاتُّ".

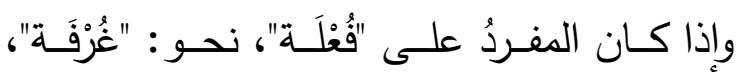

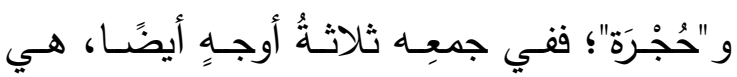

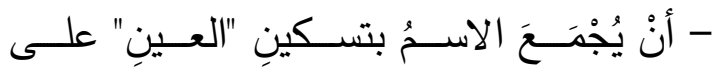

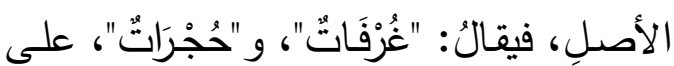

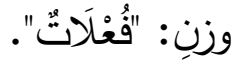

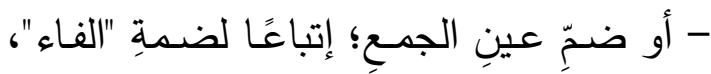

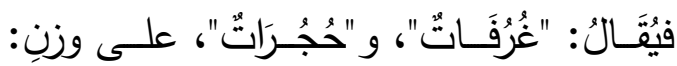

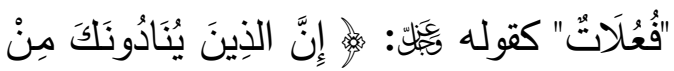

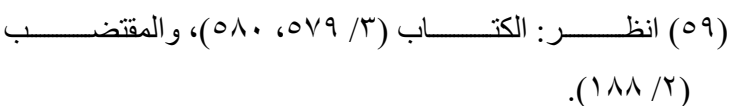

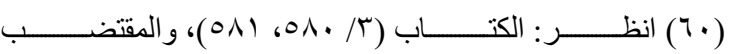
$((\wedge \vee / Y)$ 
قبيـل اخـتلاف السـمات الصــوتية بـين قبائـل

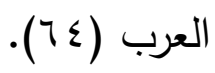

وعند استقراءِ ضوابطِ المتنافراتِ الحركيةِ في

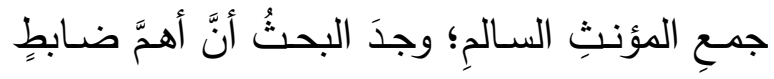
وضــعَه الصــرفيون للإتبــاع الحركـيّ بـين فــاءِ

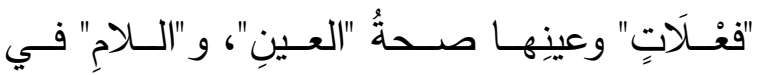

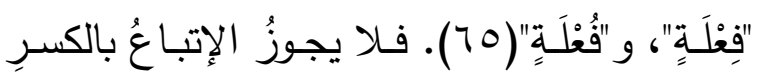

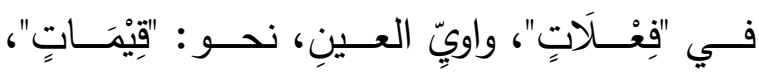
و "دِيْمَاتِ"؛ استثقالًَ للكسرةٍ على "الياء" المُعَلَّةِة من "الواوِ، المكسورِ ما قِبلَها. ولا يجوزُ الإتباعُ بالكسرِ في "فِفْـَلَتِ"، واويّ

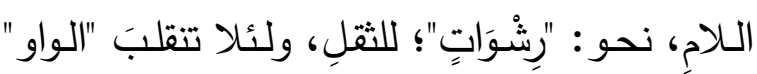

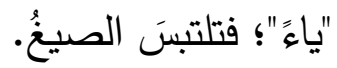
ولا يجوزُ الإتباعُ في "فُعْلَاتِ" مع معتلِّ العينِ

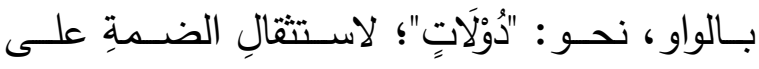

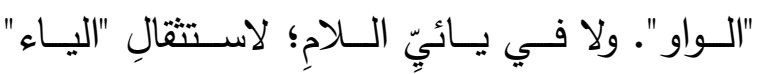

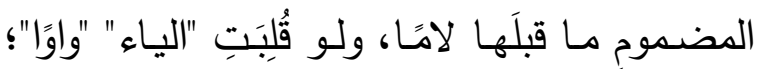
لالتبستِ الصيغُ. ويلاحظُ أنَّ احترازاتِ إتبـاعِ المعتلِّ "العينِ"،

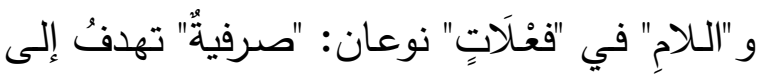

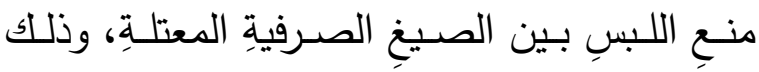
بالنظرِ للواوِ والياءِ على أنهما حرفان "صـامتان". و "صوتية" تَنْتَكِرُ الثقلَ والتنافرَ الحركيَّ، فتحريكُ

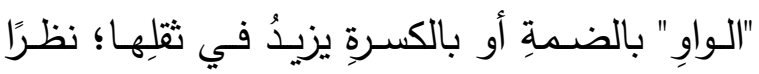

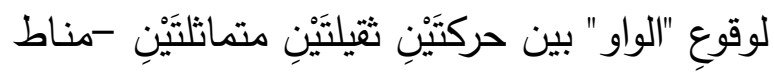

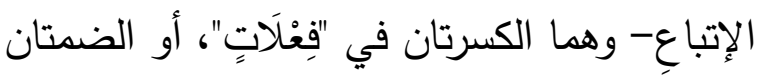

( § T) انظر : لغة تميم، در اسة تاريخية وصفية ( • ؟ ).

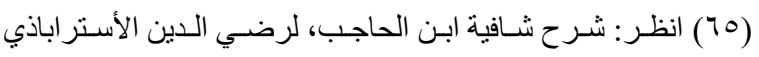

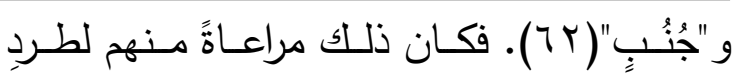
البابِ في كِلَا البناءَيْنِ، وحملِ بنايٍِ الجمِِ على

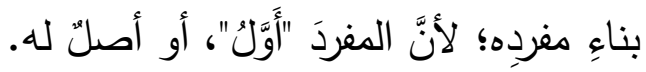

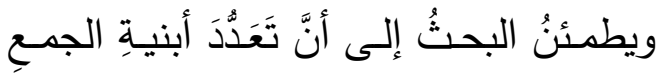
بـالألفِ والتـاءِ فِي: "فعـلَتٍِ" بالتسـكينِ كوهـو

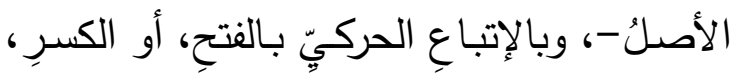
أو الضمّ يُمَتِّلُ لغاتِ العربٍ وعاداتِهم النطقيةَ في إِي

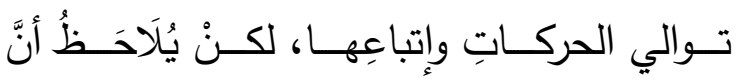

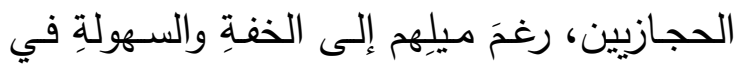

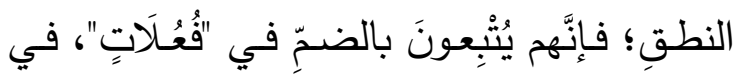
حين يُنْسَبُ التسكينُ في "فُعْلَاتٍِ" إلى التميميّين، وناسٍ من قيسٍ (بT).

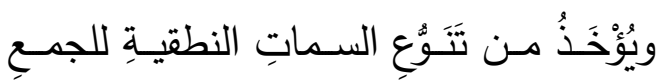

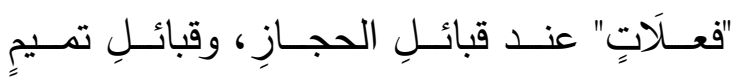
نتيجتان:

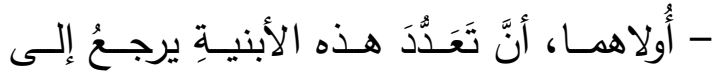
تطورِ أصواتِ حركاتِها، على غِرَارِ ما حدثَ

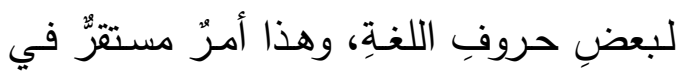
الدرسِِ الصوتيّ الحديثِ.

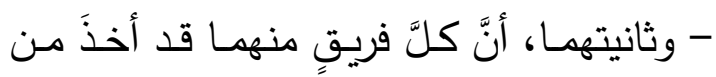
الآخرِ بعضَ ما هو جائزٌ عنده، فلحَلَّ هذا

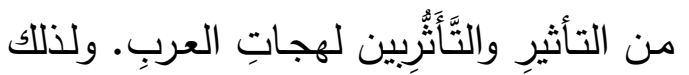
بنى الاكتور ضاحي عبد الباقي رأيَه على أنَّ نهجَ تميم الخاصَّ واختلاف لغتها مـع اللغـة

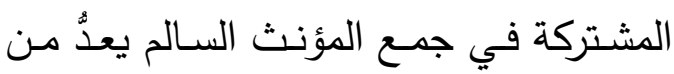

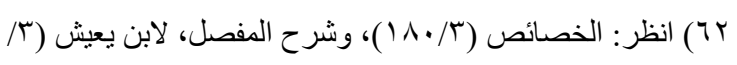
. $\left(r \leq \Lambda_{-} r \leqslant V\right.$

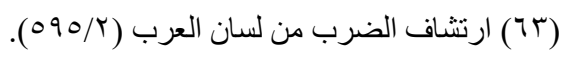


وسييويه، و "العين" هي المحذوفة عند أبي الحسن

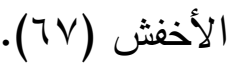

وتختلفُ نظرةُ الصرفيين القدماء إلى مَجِيء بناءِ "تَفْعُولٍ" تامَّا وناقصًا من الأجوفِ في العربيةِ

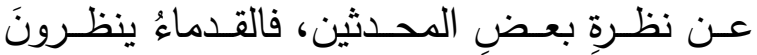

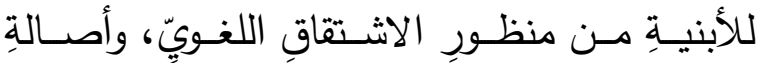
"جذرِ" الكلمةِ الذي يُحْتَكُُ إليه في إعلالِ المشتقاتِ

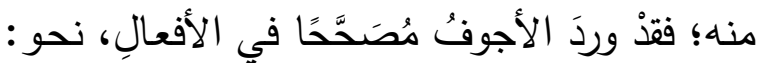

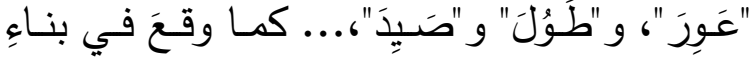
"مَفْعُولٍ"، فـإجراءُ المعتلِِ مجـرى الصـحيح كـان

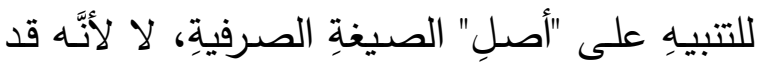

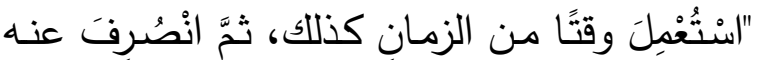
فيما بعد إلى هذا اللفظٍ"(7^).

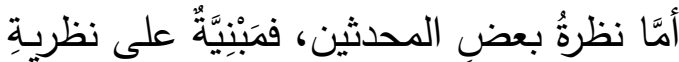

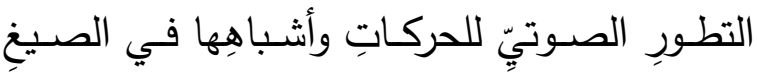
الصـرفيةِ عندَ العربٍ، فقد ذهبَ الدكتور رمضـان

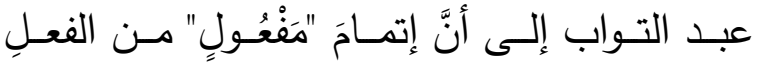

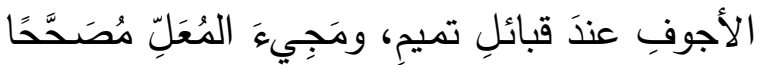

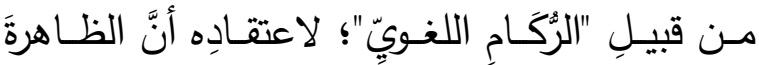

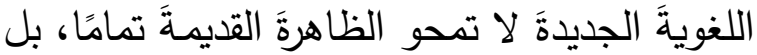

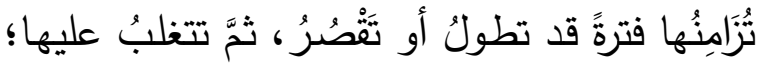

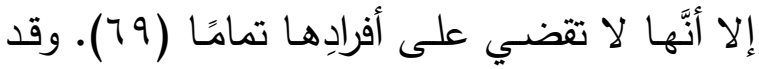
وافقَه في ذلك الدكتور فوزي حسن الشايب؛ فجعلَ

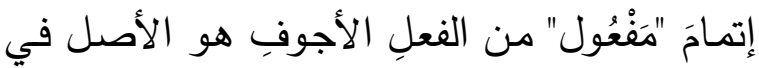

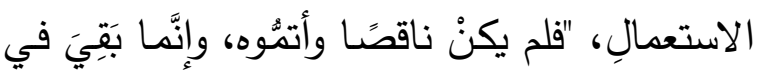

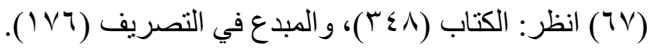

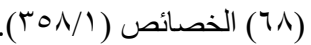
(79) رأي في تفسير الثـواذ في لغـة العـرب، ضـمن كتـاب بحـوث ومقالات في اللغة (90_70).

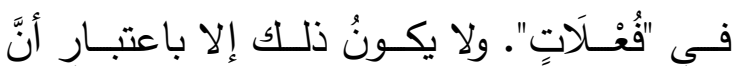
"الواو"، أو "الياء" شِبْهَا حركةِة. ودليلُ الثنقلِ عند

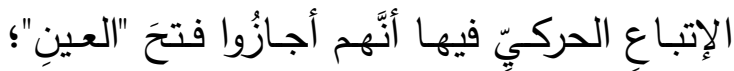

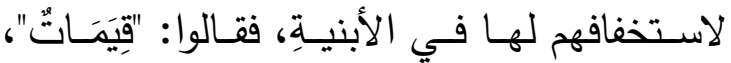

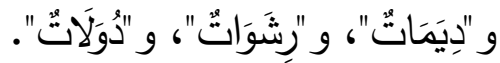
r) توالي الحركاتِ وأششباهِ الحركاتِ في بنـاءِ

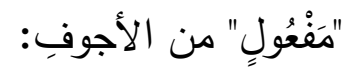

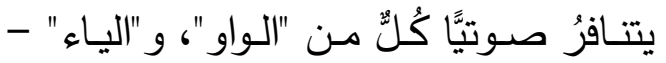
بوصفِهما شِبْهَيْ حركةٍة- مع الضمةِ القصيرة في في

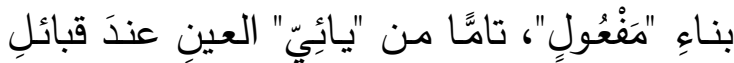

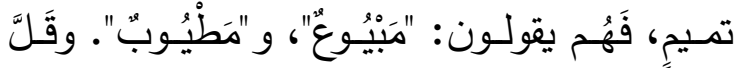

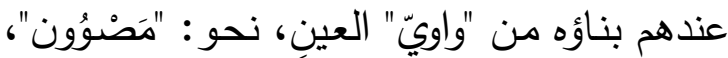

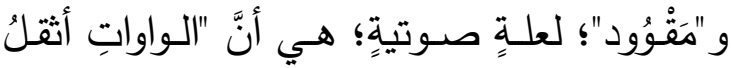
عليهُ مـن اليـاءاتِ، ومنهـا يَفِرُُون إلىى اليـاءِ؛

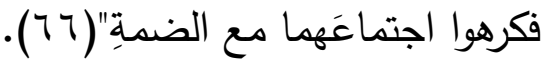
وتَحَاِِيًا لهذا الثقلِ في أثناءِ انتقالِ جهازِ

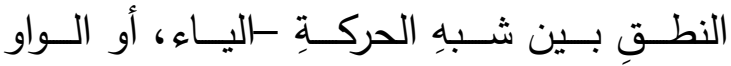

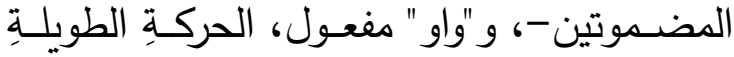

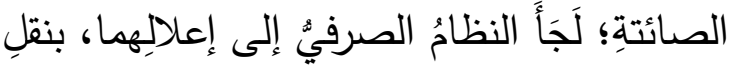
الضمةِ إلى الحرفِ قبلهما، وحذفِ "عين" الكلمةِ؛ لالتقــاءِ السـاكنين. وهـذا الإجـراءُ معـزوٌ لقبائـلِ الحجازِ الذين يميلون إلى السهـولِة في النطقِ،

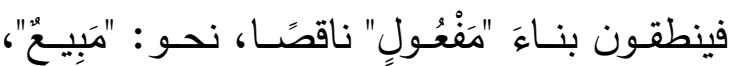
و "مَطِيبّ"، على خلافٍ بين الصرفيين العربٍ في

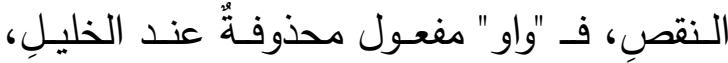




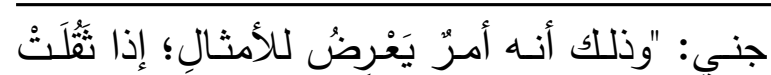

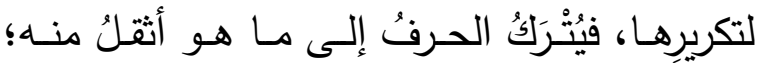
ليختلفت اللفظان؛ فَيَخِفَّا على اللسانِ" (VY).

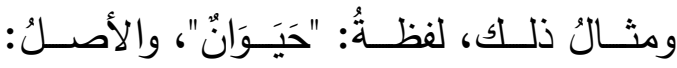

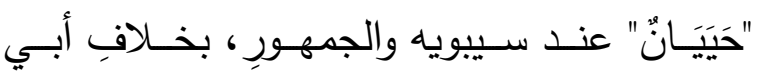

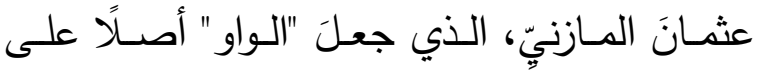
غيرِ قياسٍ (VT).

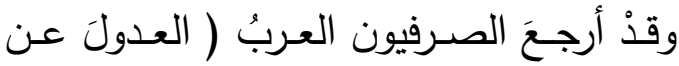
الثقيلِ إلى الأثتلِل ) في هذه الصيغةِ إلى عِلَّتَيْنِ:

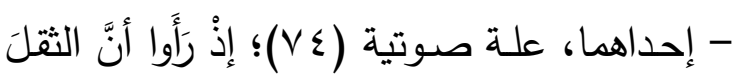
حادثُ من صعوبةِ نطقي "الياءين" المفتوحتين

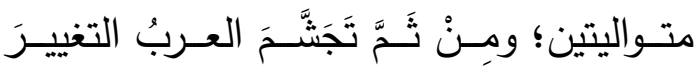

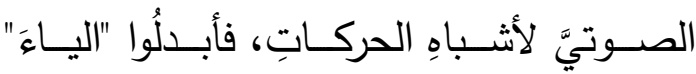

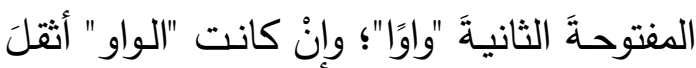
من "الياء" في النطقِ؛ تحاميًا للتضعيفِ فيهما.

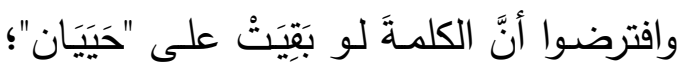

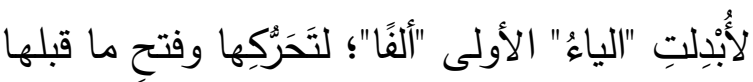

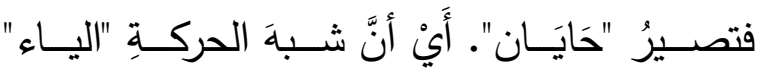

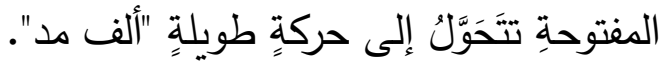
- والثانية، علَّة صرفية (V0)؛ لأنَّ تواليَ المثلَيْنِ

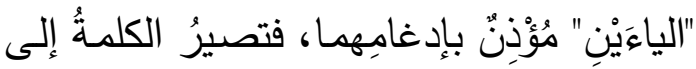

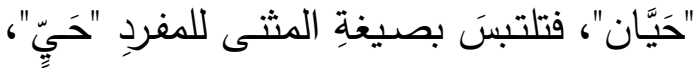

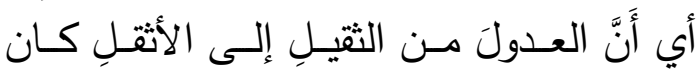

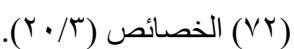

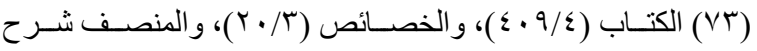
كتاب التصريف (1) (1). (1). ( ع (V) انظر هذه العلة في: الكتاب (ع/9 • ع))، و المنصف شرح كتاب التصريف (01) (0).

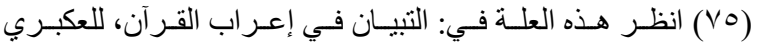
$(1 \cdot r 0 / r)$

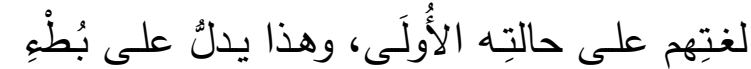

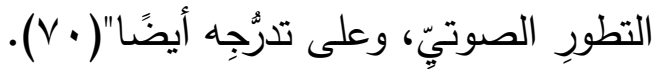

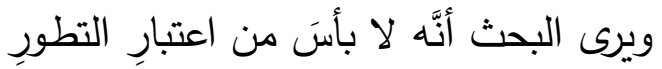

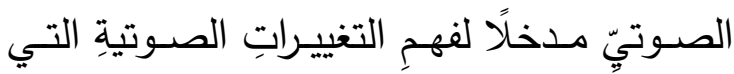

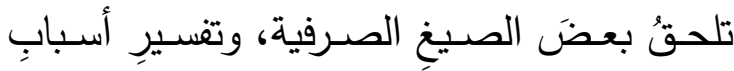
قبولِ النظامِ الصرفي للتنافرِ والثنقلِ بين أصواتِ

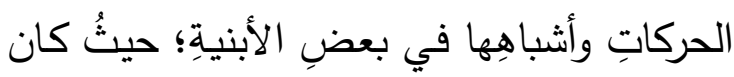

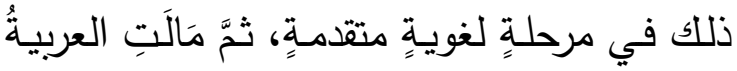
إلى التخفيفِ؛ بإعلالِها وحذفِهِا للتخلصِ منهما.

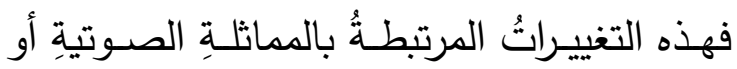

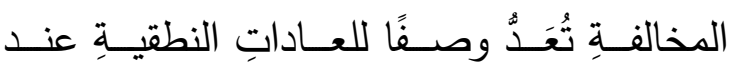
المتكلمِينَ باللغة، وليست قانونًا لغويَّا مُلْزِمًا لهم

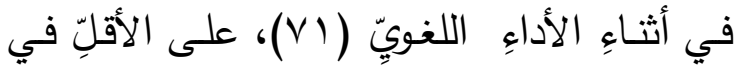

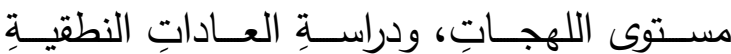
الخاصَّةِ بعضِِ القبائلِ العربيةِ. ؛) العـدولُ فـي الحركـاتِ وأثــباهِ الحركـاتِ

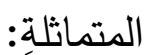

أكثرُ ما يقعُ مطردًا من الأبنيةِ الصرفيةِ ما لما

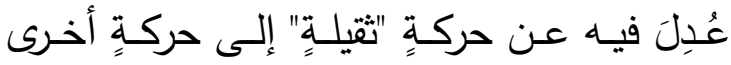

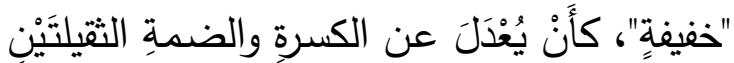
إلىى الفتحـة الخفيفةِة، وهذا جـائزّ في النظـامين الصوتيّ والصرفيّ؛؛ لدفع تنافِر الحركاتِ الثقيلةِ

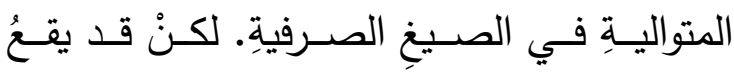

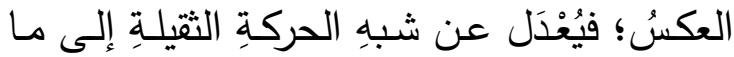
هو أثقلُ منها، وهذا لا يُجيزه النظامُ الصـوتيُّ،

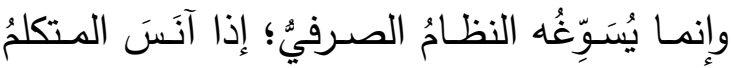

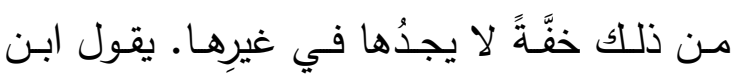




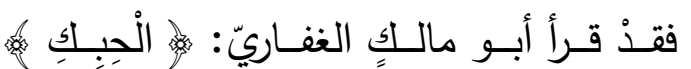

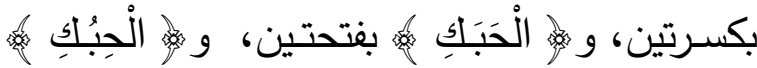

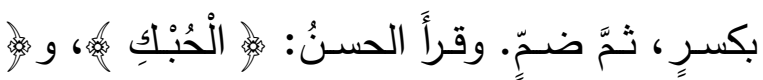

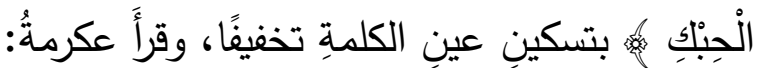

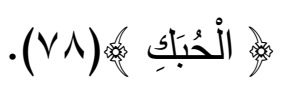

حيثُ عُدِلَ عن الضمةِ، وهي أثقلُ الحركاتِ

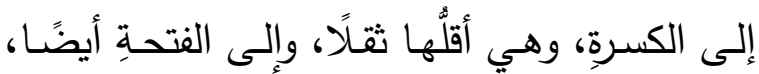

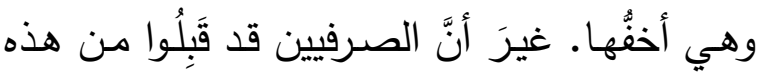

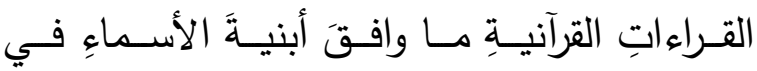

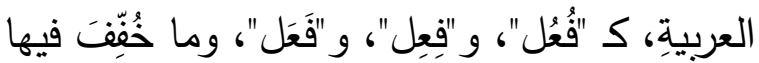

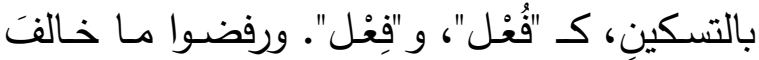

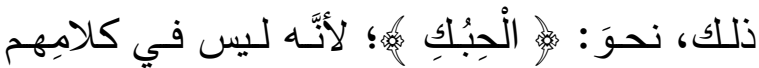
"فِعُل" أصلًَ؛ لكراهيةِ الانتقالِِ بين الكسرِ والضِّ.

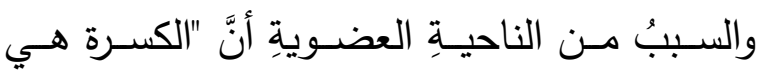

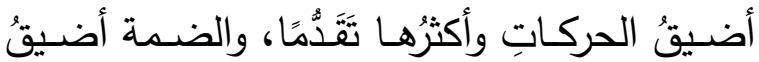
الحركاتِ وأكثرِها تراجعًا، والناطق يَصْعُبُ عليه أَنْ

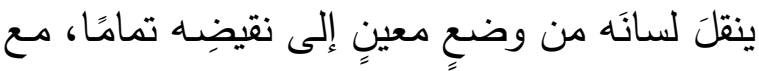
التزام السرعةِ العاديةِ في الأداءِّ"(V9). ومع ذللك، فقد أحسنَ ابن جني الظنَّ بالقارئَ، فقالَ: "لعلَّ الذي قراً بـه تداخلَتْ عليه القراءتان

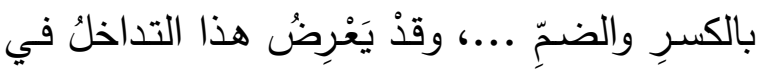

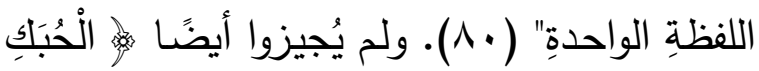

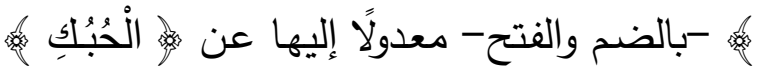

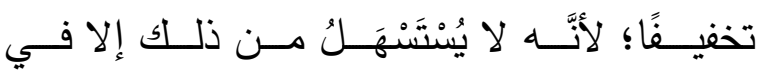

انظر : المحتسب في تبيين وجوه شواذ القراءات والإيضساح عنها (VA)

( $(\Gamma ั 4 / \Gamma)$

(V9) المنهج الصوتي للبنية العربية، رؤية جديدة في الصرف العربي (O)

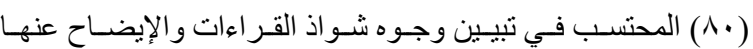

لمعنَى صـرفيّ، ولأمسنِ اللـبسِ بـين الصـيخ

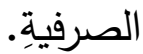

ومسن أمثلـةِة ذلك أيضًا: "حَيْوَةُ"، والأصسل:

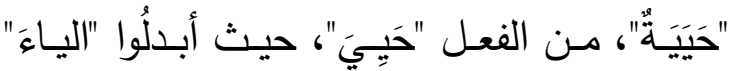

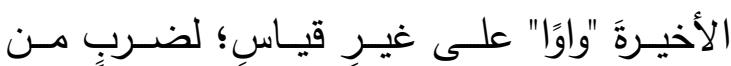
التخفيفِ بالمخالفةِة الصوتيةِ بين الحرفَيْنِ؛ لأنَّهم

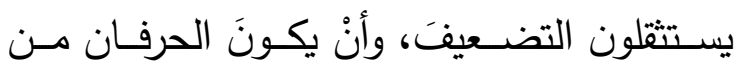

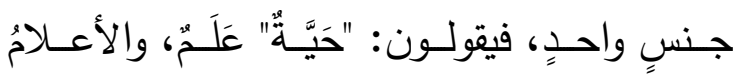
يُحْتَمَلُ لها كثيرُ من كُلَفِ الأحكامِ (VT)

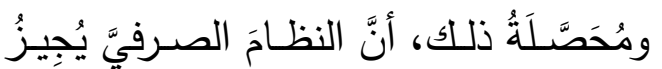
العدولَ عن الثقيـلِ منها إلى الأثقلِ سوإن كانَ

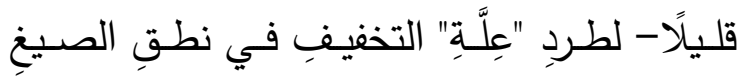

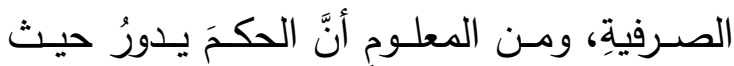

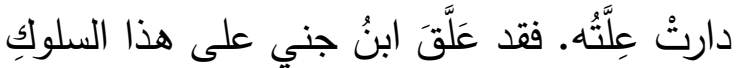
اللغويّ الذي يبدو في ظاهرِه مخالفًا لبناءِ العربيةِ

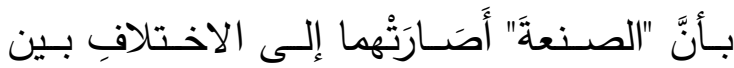

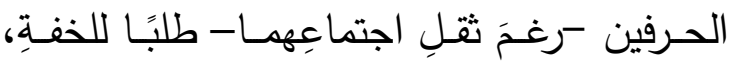
وهروبًا من تتافرِ الأصِواتِ عندَ توالي الحروفِ المتماثلةٍِ (VV)

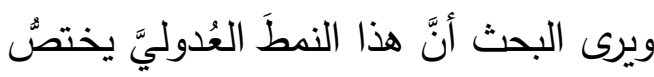
أَكْثَرَّهُ بأشباهِ الحركاتِ فقط، وهي "الِواو "، و "الياء"

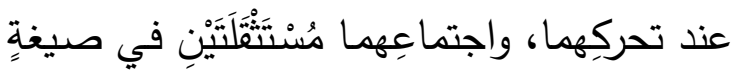
واحدةٍٍ أمَّا الحركاتُ القصيرةُ، فيكونُ الميلُ فيها

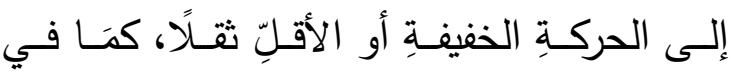

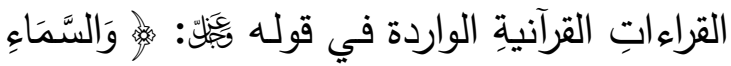

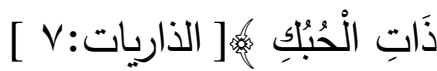

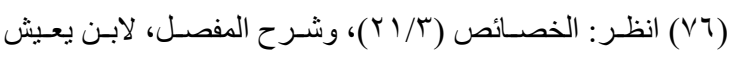

$(\xi Y \cdot / 0)$ 


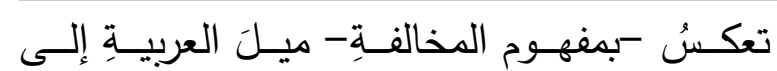
التخفيفِ، كما تكثفُ لنا حقيقةً علميةً تتعلق باللغةِ ومسـتعمليها، وهـي طبيعـةُ التطـورِ الصـوتيّ في الأبنيــة الصــرفيةِ، والفـروقُ الفرديـةُ بـين القبائسلِ العربيـةِ في قبـولِ الثقـلِ الحركيّ والصـوتيّ عندـ نطقِهِا. ورغمَ أنَّ العاداتِ والخصائصِِ النطقيةَ هي السائدةُ؛ فإنَّ بعضَ القبائلِ التي تميلُ إلى السـهولِةِ والتخفيفِ قد تَجَشَّمَتِ النطقَ بالمتنافراتِ الصسوتيةِ في بعضِ الأبنيـةِة، وصـارَتْ جـزعًا مـن معجمِهـا اللغويّ.

هذا، وقٌْ توَصَّلَتِ الدراسةُ إلى النتائجِ الآتيةِ:

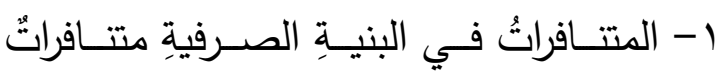

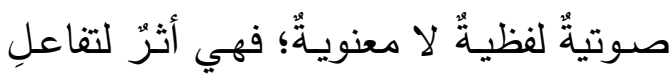

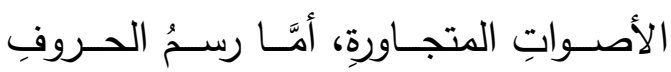
والحركاتِ؛ فهيئاتُ عارضةٌ لها. لها. Y- أحكــامُ المتـــافراتِ الصــوتيةِ علـى أســاسِ

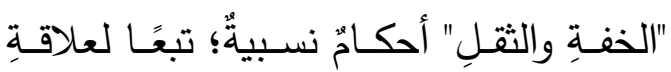
الاسـتعمالِ اللغـويّ الخـاصِّ بالـذوقِ اللغـويّ

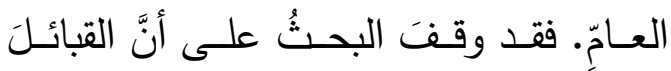
الحجازيـةَ التي تميـلُ للسـهولِِ والتخفيفِ قد

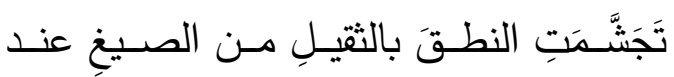
القبائلِ البدويـةِ، كتمسيمٍ وقيسٍ. ولذلك يجبُ

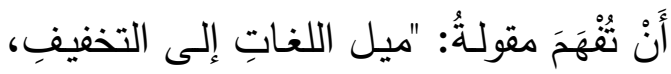
واقتصسادِ الجهدٍ العضـليّ" في سياقٍ خـاصٍِ بالنظامين الصوتيّ والاشتقاقيّ لكلِّ لغةٍِ، أو

$$
\text { لكلِّ مستوى لهجيّ على حدَةٍ. }
$$

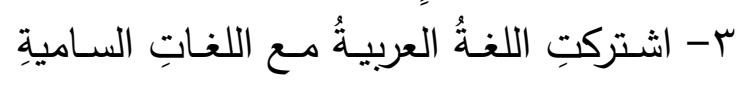
في وقـوعِ بعضِ المتــافراتِ الصـوتيةِ في أبنيتها الصرفيةِ، مع اختلافاتٍ طفيفةٍ كاشفةٍ

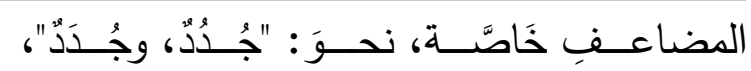

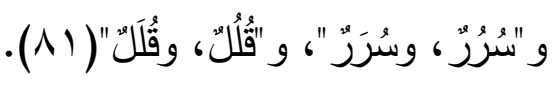
وكذللكَ لا يقعُ العدولُ بين الحركاتِ الطويلةِ

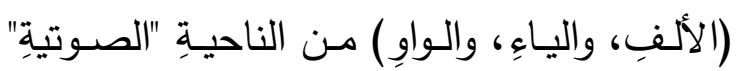

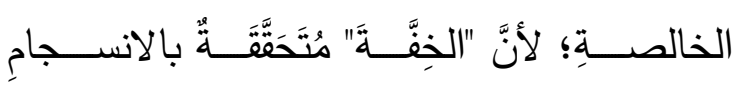
الصسوتيّ بين كُلِّ حركةٍ "طويلةٍة" منها، وبين مـا يناسبُها من الحركاتِ القصيرةٍ (الفتحة، والكسرة، والضــمة). لكـنْ مـن الناحيـةِة "الصـرفيةِّ" يمكـنُ العدولُ عن "الواو"، و "الياء" إلى "ألفِِ" المدِّ؛ إذا كانتَا شِبْهَيْ حركةِة، وتحركتَا بالفتحـة، وكان مـا

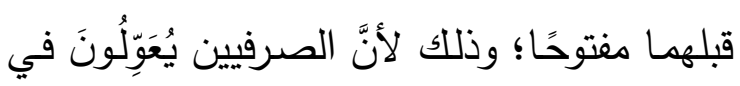
الصيخِ الصرفيةِ على الاشتقاقِ، وَرَدِّ كُلِّ صيغةِِ

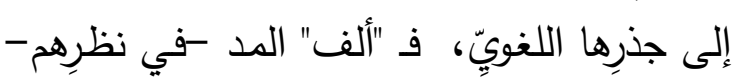

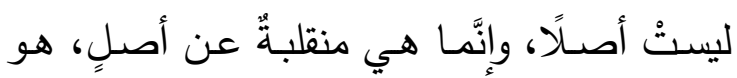
"الواو"، نحوَ : "قَالَ، قَوَلَ"، أو "الِياء "، نحوَ : "بَاعَ،

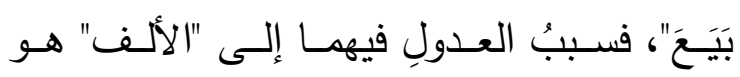
استثقالُ الحركةِ عليهما.

\section{خاثمة البجث}

قامَتْ فكرةُ البحثِ على أساسِ وجودِ بعضِ المتــافراتِ الصـوتيةِ الجـائزةِ في النظـامِ اللغـويّ للأبنيةِة الصرفيةِ بضوابطَ محددةٍ، وهي مرفوضـةُ في الدرسِ الصسوتيّ؛ لأسبابٍ فسيولوجيةٍ تتعلَّقُ بالتثـلِ، والجهدِ العضـلِيّ المبـذولِ فـي نطقِهـا، والميـلِ إلـى خِفَّـةِ الأوزانِ، والمقــاطعِ فـي بنيـةِ الكلمةِ. فإذا كان الاستثناءُ يؤكدُ القاعدةَ المطردةَّ؛ فإنَّ الإجراءاتِ الصرفيةَ التي سَوَّغَتْ وقوعَ هذه المتنافراتِ الصسوتيةِ في حروفِ الكلمسِة وحركاتِها

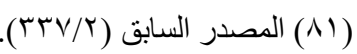


بين الصوتين المتنافرين بصوتِ حرفٍ آخرَ لعلاقةٍ صوتيةِ وصرفيةٍ بينها داخلَ الكلمةِ. - Vتـاولَ الصـرفيون العـربُ بحـَت الحركـاتِ

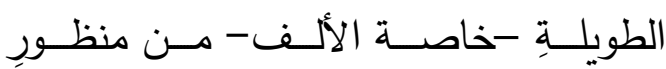
الاشـتقاقِ اللغـويِّ، وردّ الصــيخِ إلـى جـذرِ الكلمةِ، فالألفت ليست حركةً طويلةً فقط، بل الب هي منقلبةُّ عن "الواو"، أو "الياء". كما أنَّهم عاملُوا "الواو"، و "الياء" على أنَّهما حركتان

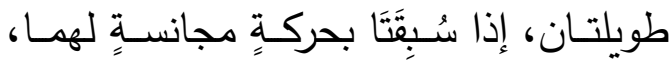

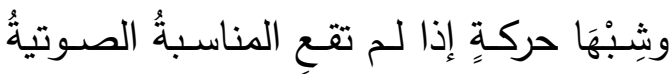
مع ما قبلها. - نظرَ الصرفيون القدامى إلى ظاهرة تصحيح الأبنيةِة المعتلةِ سوهي من الثقل في أصواتِ

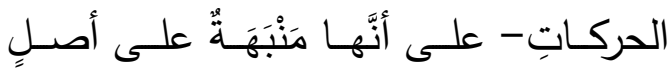
افتراضـيّ غيرِ مستعملِ، أو لـم يثبت عليه دليـل تـاريخي. لكنَّ المحدثين رَأَوْا أنَّها مـن قبيلِ الركام اللغويّ الذي استعملته العربٍ، ثُمَّم

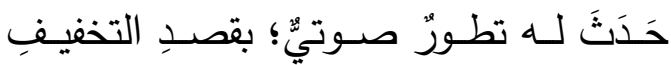
وسهولِِ النطقِ

9- ظـاهرةُ العـدولِ مـن "الخفيـفِ إلـى الثَتِلِلِ، ومن "الثقيلِِ إلى الأتقلِِ" في بعضِِ الصسيخ من مقتضياتِ الصناعِِ الصرفيةِ، فهي تعودُ لأسـبابٍ صـوتيةٍ ذوقيـةٍ، ولأسـبابٍ صـرفيةٍ، تتعلقُ بالمعنى، وأمنِ اللبسِ بين الصيخ، أو أو إلحاقي صيغةٍ صرفيةٍ بصيغةٍِ أخرى، أو طرد البابِ في الأبنيةِ الصرفيةِ.

المصادروالمراجع

1-ارتشاف الضرب من لسان العرب، أبو حيان الأندلسي، تحقيق الدكتور رجب عثمان تحمد.
لخصوصسيةِ كُلِّ لغــة بنظامَيْها الصـوتيّ، والاشتقاقيّ. ع- لم يُجْزْ الدرسُ الصـوتيُّ -قديمًا وحديثًا -

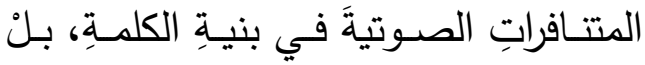
أجازَهـا الـدرسُ الصـرفيُّ بضـوابطَ وشـروطٍ محددةٍ نظرًا لاختلافِ معطياتِهما، فالأول، يعنى بالعمليةِ الفسيولوجيةِ للصوتِ اللغويّي، وصفاتِه، بوصفِه أصغرَ وحدةٍ صوتيةٍ في

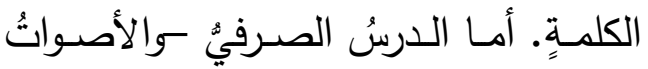

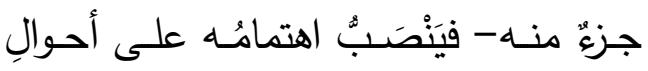

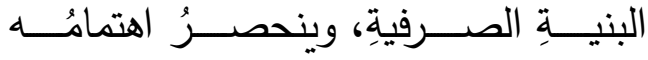

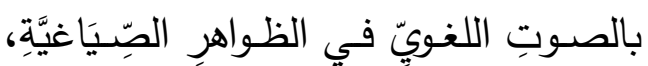
كالإعلالِِ والإبدالِِ، والإدغام، والإمالِّة...،

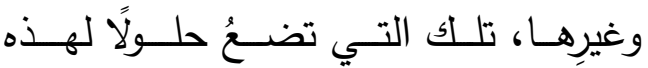
المتتافـراتِ الصــوتيةِ، وفـي حـالِ عجـزِ النظــامِ اللغــويّ عَنْ حلِّهـا؛ فإنَّـهـه يُجيزهـــا بضوابطَ محددةٍ مأخوذةٍٍ من إمكاناتِ اللغةِِ نفِيسها.

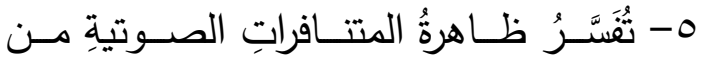
جهتين: الأولىى، عجز الظـواهرِ الصـرفيةِ

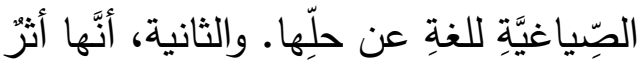
للتطورِ الصوتيّ للأبنيةِة في رحلتِها اللغويةِ

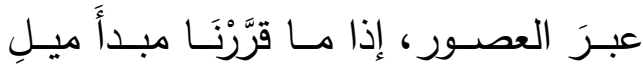
اللغـاتِ إلى التخفيـِِ، بـدليلِ وجـودِ أبنيـةٍِ صرفيةٍة يجوزُ فيها إدغامُ المثلين، وفَكِّهِيا

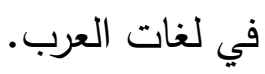
ج- التجنـيسُ الصــوتئٌ مسـوغُ لقبـولِ بعـضِ

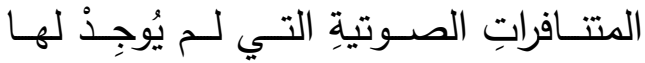
النظامُ الصرفيُّ حَلَّا حاسمًا، وهو التقربُِّ 
العامـة للكتــاب، القــاهرة، الطبعـة الرابعـة

$$
\text { . }) 999
$$

9-دلائـل الإعجـاز ، عبـد القـاهر الجرجـاني،

تحقيق محمـود حمح شـاكر • الهيئة المصـرية

العامة للكتاب، القاهرة، طبعة ... . بم.

• ا- ديـوان العجـاج، بروايـة الأصــعي، تحقيـق

الدكتورعبد الحفيظ السطلي. مكتبة أطلس،

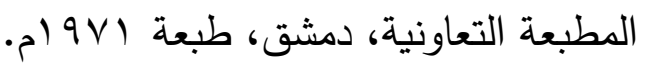

1ا- رأي في تفسير الشواذ في لغة العرب، ضمن

كتـاب بحـوث ومقـالات في اللغـة للـدكتور

رمضــان عبــد التــواب. مكتبــة الخــانجي

بالقاهرة، الطبعة الأولى ب^ه (م.

r ا- سر صناعة الإعراب، أبو الفتح عثمان بن بن

جني، تحقيق الـدكتور حسن هنداوي. دار

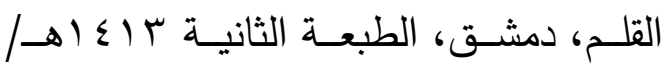

$$
\text { . }) 994
$$

سا - شرح التسـيل، ابن ماللك الأندلسي، تحقيق الـدكتور عبــد الـرحمن السـيد وزميلـه. دار

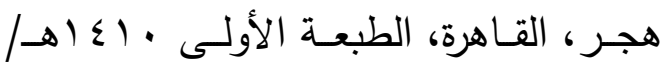

$$
\text { . }) 99 \text {. }
$$

ـ ا- شـرح شـافية ابـن الحاجـب، رضــي الـدين الأســتراباذي، تحقيـق تحمد نـــور الحســن،

وزميلَيْه. دار الكتب العلمية، بيروت، طبعة

$$
\text { . } 919 \mathrm{r} / \mathrm{A} / \mathrm{s}
$$

10- شـرح المفصـل، موفق الـدين ابـن يعـيش، تقديم الدكتور إميل بديع يعقوب. دار الكتب

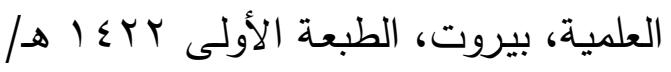

$$
\text { . }
$$

مكتبـة الخـانجي، القـاهرة، الطبعـة الأولى

$$
\text { - م) } 991 / 81 \leq 11
$$

ץ- أثـر القـوانين الصــوتية فـي بنـاء الكلمـة،

للدكتورفوزي حسـن الشـايب. عـالم الكتب

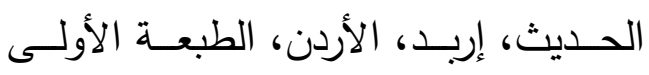

$$
\text { . }
$$

r- الأشباه والنظـائر في النحو، جـلال الدين

السيوطي، تحقيق الدكتور فـايز ترحيني. دار الكتاب العربي، بيروت، الطبعة الأولى

$$
\text { .م) } 9 \wedge \leq|ه| \varepsilon
$$

ع- البيـان فـي إعـراب غريــب القـرآن، أبــو

البركات بن الأنباري، تحقيق الدكتور طه

عبد الحميد طـهـ. الهيئة المصـرية العامـة

للكتاب، القاهرة، الطبعة الثانية ج ـ . بـ.

0- التبيــان فـي إعـراب القـرآن، أبــو البقــاء

العكبـري، تحقيـق علي تحمد البجـاوي. دار

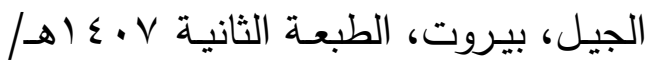

$$
\text { . ) } 9 \wedge \mathrm{V}
$$

צ- التذييل والتكميل في شرح كتاب التسهيل، أبو حيان الأندلسي، تحقيق الدكتور حسن

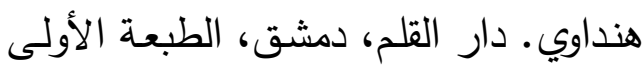

$$
\text { . . . . . . }
$$

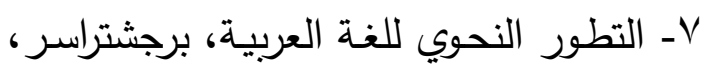
محاضـرات جمعها الدكتور رمضـان عبد التواب. مكتبـة الخـانجي، القـاهرة، الطبعـة

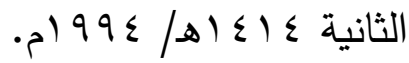
^- الخصـائص، أبو الفتح عثـان بـن جنـي، تحقيق قحمد علي النجار • الهيئة المصـرية 
گ צ- لغـة تميم دراسـة تاريخيـة وصفية، الدكتور

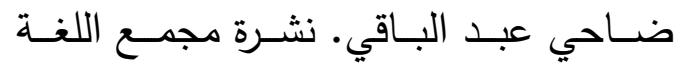

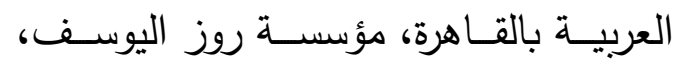

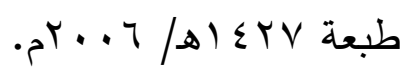

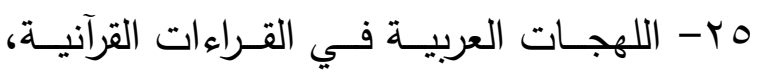

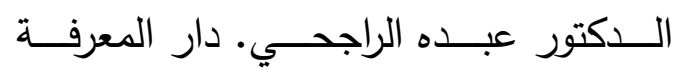
الجامعية، الإسكندرية، طبعة 999 (م.

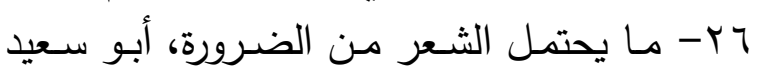

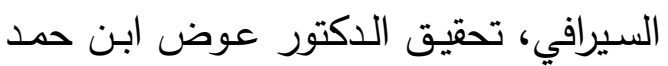

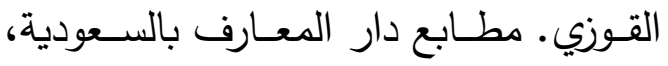

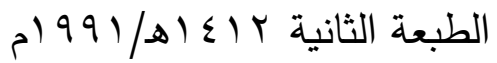

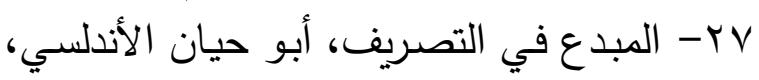
تحقيـق الدكتور عبد الحميد السيد طلب.

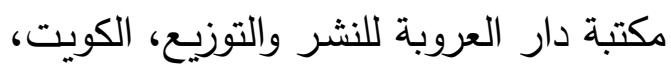

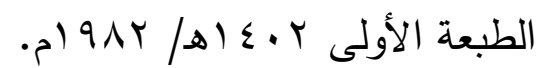

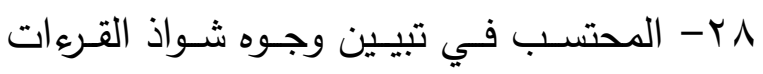
والإيضاح عنها، أبو الفتح عثان ابن جني،

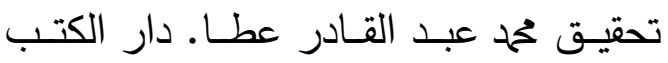

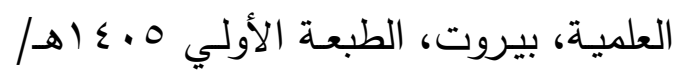
-p) $9 \wedge \leqslant$ و ج- المزهر في علوم اللغة وأنواعها، جلال الدين

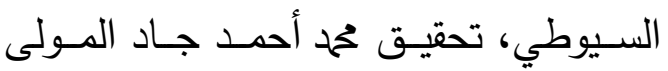

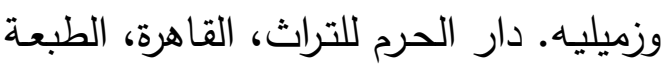
الثالثة، بدون تاريخ.

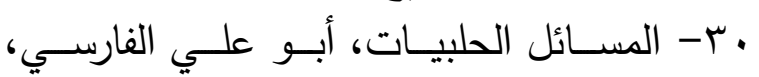

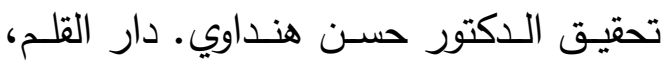

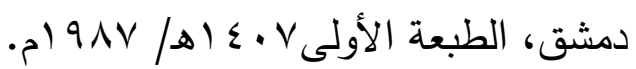

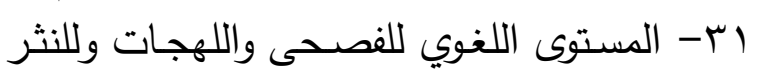

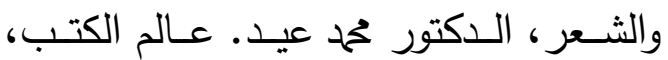
القاهرة، بدون طبعة أو تاريخ. rr- معاني القرآن، أبو زكريا الفراء، تحقيق أحمد لـاري

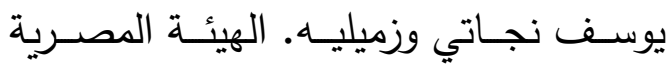
العامــة للكتـاب، القـاهرة، الطبعــة الثانيــة . 9191 .
11 - ظاهرة التخفيف في النحو العربي، الدكتور أحمـد عغيفـي. الــار المصـرية اللبنانيـة،

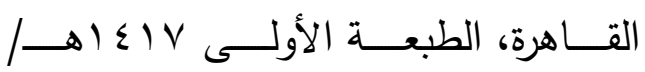
. $) 997$ IV - فقـهـ اللغـات السـامية، كـارل بروكلمـان، ترجمة الدكتور رمضـان عبد التواب. نشرة جامعة الرياض، المملكة العربية السعودية، طبعة كو أهـ/9VV 1 ا- فقـهـ اللغــة وسـر العربيـة، أبـو منصــور الثعالبي، تحقيق مصطفى السقا، وزميلَيْه. دار الفكــر للطباعــة والنشــر والتوزيــع، القاهرة، بدون طبعة أو تاريخ. 19- الكتاب، سيبويه، تحقيق عبد السـلام حمد هـارون. دار الجيـل، بيـروت، الطبعـة الأولى، بدون تاريخ. • r- كتاب العين مرتبًا على حروف المعجم، الخليل بن أحمد الفراهيدي، تحقيق الدكتور عبد الحميد هنداوي. دار الكتب العلمية،

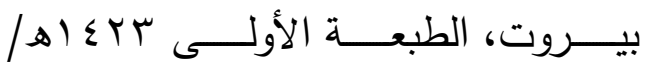
$\cdot r^{2} \cdot \varepsilon$ ا اب- الكثـاف عـن حقــائق التنزيـلـل وعيـون الأقاويـل في وجـوه التأويـل، محمـود بـن لـن عمر r r- الزمخشـري، تحقيـق الـدكتور عبد الـرزاق

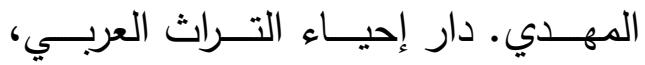

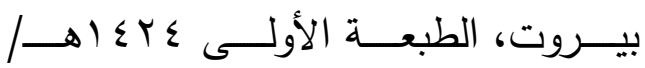

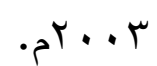
r

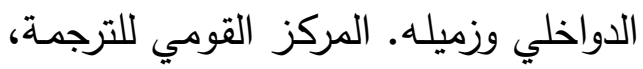

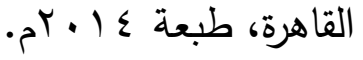


بr- المعرب من الكلام الأعجمي على حروف بr- المنصف شرح كتاب التصريف، أبو الفتح

عثــان بـن جنـي، تحقيـق حمه عبـد القـادر

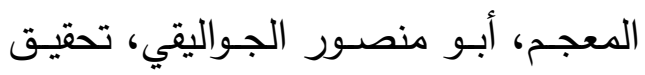

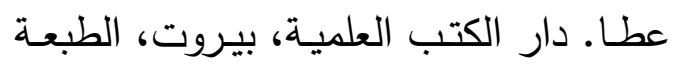

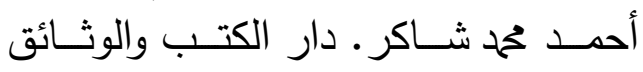

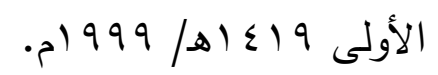

القومية، الطبعة الثانية 979 (م.

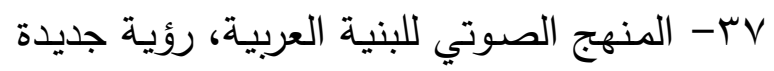

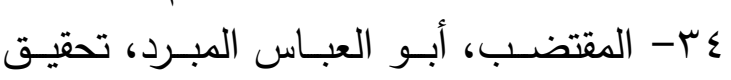
في الصـرف العربي، الدكتور عبد الصبور

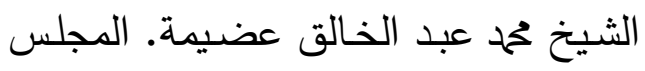

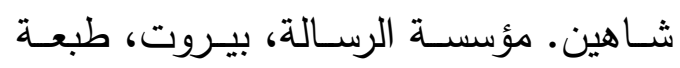

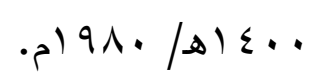

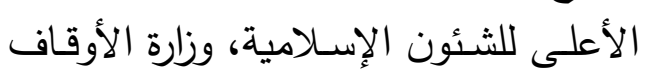

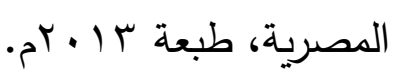
^ץ- من وظائف الصـوت اللغوي، محاولـة لفهح هب- الممتع الكبير في التصريف، ابن عصفور

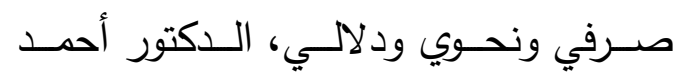
الأشبيلي، تحقيق الدكتور فخر الدين قباوة. كثــك. حقـوق النشـر محفوظــة، بـدون دار

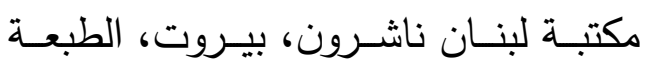

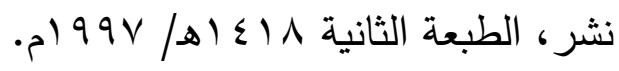

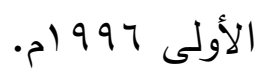

